\title{
Psalme-Blade til Kirke-Bod En brevveksling mellem Grundtvig og hans præstevenner i foråret 1843
}

\author{
Af Jette Holm
}

\section{Indledning}

Grundtvigs prædikener fra 1840 'erne er for øjeblikket ved at blive udskrevet (på Center for Grundtvig Studier i Århus) med henblik på udgivelse. De første 3 bind med et kommentarbind udkommer sept. 2003 i forbindelse med Aarhus Universitets 75 års jubilæum, (på Forlaget Vartov).

I 1843 udarbejdede Grundtvig et salmebogstillæg: Psalme-Blade til Kirke-Bod, som modtræk til Mynsters: Udkast til et Tillaeg til den evangelisk-christelige Psalmebog. (Foreløbig udgivet som Prøve). Kbh. 1843.

Arbejdet med prædikenerne fra I840'erne har gjort det nærliggende at studere dette salmebogstillæg og dets tilblivelse nærmere, da salmer og prædikener hører uløseligt sammen hos Grundtvig.

Til belysning af Grundtvigs indledende arbejde med Psalme-Blade til Kirke-Bod i foråret 1843, er brevene af uvurderlig betydning.

Desværre lader de breve, der er trykt, og som vedrører salmebogstillægget, meget tilbage at ønske. Grundtvigs egne breve fra foråret 1843 er ganske vist alle trykt ${ }^{1}$, men i de fleste tilfælde mangler præstevennernes svar på Grundtvigs breve. $\mathrm{Og}$ det er særlig slemt, hvad diskussionen omkring salmebogstillægget angår. Grundtvigs breve er helt uforståelige, når han kommenterer salmeforslag og enkeltheder i en salme, hvis man ikke har kendskab til de forslag, der ligger til grund fra en af hans venner.

Så snart Grundtvig havde læst Mynsters forslag til et salmebogstillæg, skrev han til sine præstevenner Peter og Ferdinand Fenger og til Peter Rørdam. Gunni Busck havde han efter alt at dømme mødt og talt med. Disse fire præstevenner blev af Grundtvig opfordret til at udarbejde salmelister, som han kunne støtte sig til i udarbejdelsen af salmebogstillægget.

Alle fire præstevenner: Peter Fenger (på vegne af begge brødre), Gunni Busck og Peter Rørdam sendte hver en salmeliste til Grundtvig, 
som han efterfølgende kommenterede i sine breve. Disse afgørende lister er for eksempel udeladt i de trykte breve.

For at råde bod på denne mangel i det trykte materiale og gøre det lettere for salmeforskningen at følge Grundtvigs arbejde med PsalmeBlade til Kirke-Bod bringes nedenfor brevvekslingen mellem Grundtvig og de fire præstevenner i foråret 1843 frem til Grundtvigs afrejse til England den 7. juni. Også Grundtvigs egne (trykte) breve bringes i det omfang, det er nødvendigt for at få den levende dialog frem. (Pastor Lars Toftdahl har været behjælpelig med afskrivningen af Grundtvigs breve).

For at gøre dialogen i brevene så tydelig som muligt bringes først brevvekslingen mellem Fengerbrødrene og Grundtvig i hele perioden, februar til maj, 1843. Dernæst følger brevene mellem Gunni Busck og Grundtvig i samme tidsrum - og til sidst brevene mellem Peter Rørdam og Grundtvig.

I brevvekslingen røber Grundtvig kun lidt af sit eget arbejde med salmerne. Da han tager til England, er Psalme-Blade til Kirke-Bod færdigt. Peter Fenger tager i sommerens løb en afskrift af Grundtvigs salmebogstillæg og mødes med Theodor Fenger og Gunni Busck, senere med Ferdinand Fenger. Det resulterer i præstevennernes skriftlige bemærkninger til forslaget (som desværre ikke findes?). -

I november bryder Grundtvig samarbejdet!

Om Grundtvigs eget forarbejde til Psalme-Blade til Kirke-Bod, om selve salmebogstillægget, dets indhold og skæbne, skal her ikke yderligere redegøres. Jeg håber at kunne udgive Psalme-Blade til Kirke-Bod senere $\mathrm{i}$ en kommenteret udgave. 
Breve fra $0 \mathrm{~g}$ til P. A. Fenger og Ferdinand Fenger

Februar - Maj 1843

Til P. Fenger ${ }^{2}$

Kiære Ven!

Khvn. 21 Febr. 1843.

Har De seet M.s Prøve-Hefte, som skulde give »de ældre og nyere Psalmer, der mest savnes« i vor forlorne Psalmebog, da er De sikkert ligesaalidt som jeg fornøiet enten med hans Udvalg eller hans Hænders Gierninger, men har De end ikke seet det, vil det dog være Dem Nok at vide, der er i alt 40 No. og deriblandt 6 af Boie, 5 af Kingo og een lille af mine med den betænkelige Melodi »Herre jeg har handlet ilde«. Da vi nu ikke kan vente, Udfaldet skulde blive bedre ved Raadførelsen med Clausen, Tryde og Rosenvinge, saa er herved, efter mine Tanker intet at giøre, uden snarest mueligt at give et andet Prøve-Hefte, der virkelig indeholder hvad vi og vore gode Venner mest savne og lade det komme derpaa an, om vi kan faae Lov at bruge det $i$ Kirken, hvad dog immer er af de muelige Ting. - Derfor beder jeg nu Dem og Broder Ferdinand snarest mueligt at sende mig en Fortegnelse paa hvad De og Deres Medsangere mest savner af Gammelt og Nyt, Busck har jeg adspurgt, Rørdam vil jeg ogsaa spørge og saa i Guds Navn giøre en Samling i en Hast, saa god som den kan blive og saa lille, som en vis Tilstrækkelighed vil taale. - Da det var godt, om Oplaget kunde blive stort og Prisen lav nok for at faae Prøven spredt over hele Riget og giøre noget Slettere næsten umueligt, har Busck og jeg betænkt at naar De og Deres Broder vil være med vil vi ene have dette for Øie og dele det mulige Tab, der ei kan blive over Kræfterne, imellem os.

Hils kiærligst fra os alle og husk med snar Betænkning paa

Deres Ven

N. F. S. Grundtvig. 


\section{Fra Ferdinand Fenger ${ }^{3}$}

Kjære Hr. Grundtvig!

Liunge d. 25. Febr. 1843

Jeg er med. Deres Brev har jeg sendt til Broder Peter og selv vil jeg besøge ham paa Onsdag, hvorpaa De saa snarest kan forvente vort foreenede Besyv Tillæget angaaende.

Den Trankebarske Missions Historie er hos Bogbinderen og har De ikke alt faaet, saa vil De i disse Dage faae 2 Exl. til Majestæterne og 1 til Dem selv. De Første har De jo været saa god at love at besørge næste Torsdag efter Modtagelsen og Sidste modtage De venligst ligesom det med Erkjendtligheds bedste Følelser sendes Dem af

Deres tro hengivne

J. F. Fenger.

$$
\text { Fra P. Fenger }{ }^{4}
$$

Kiære Hr. Grundtvig!

Slotsbjergbye d. 27. Fbr. 1843.

Deres Brev har glædet mig meget. Strax jeg fik det, sendte jeg det til Ferdinand og foreslog ham hvordan vi skulde mødes, og igaar fik jeg Brev fra ham i samme Anledning, saa vore Breve have krydset hverandre. I denne Uge venter jeg at De skal modtage Optegnelse paa, hvad vi mene der bør optages i Samlingen. Det Vanskelige vil ikke bestaae i - saa god er Herren mod os, saa meget Godt har han ladet os arve - at finde Psalmer, som det for Christne kan være glædeligt og opbyggeligt at synge; men, formedelst den indskrænkede Plads, hvilke der skal lades ude af dem, man nødigt savnede. Jeg har begyndt at gjennemgaae Kingo og Sangværket, og skal nu til at gjennemgaae Brorson og Pontoppidans Samling inden Ferdinand kommer paa Onsdag. Det er mangengang som lukkede man Døren for en kjær Ven, naar man synes der ikke kan være Plads for denne eller hiin Psalme, man gjerne vilde have med. Dog kan man ogsaa betragte det saaledes: jeg har mange gode Venner men da jeg ikke har stor men kun lille Plads, indbyder jeg, til jeg faaer bedre Lejlighed, Nogle af dem jeg helst seer hos mig, og som passer bedst for hverandre. I Regelen kommer de lange Psalmer vel til at vige for de korte, de som have en eller anden Feil i Formen, for dem Ingen for Formens Skyld lettelig ville kunne støde sig over, de, som have bekjendte Melodier, foretrækkes for dem der maatte sættes Melodier til. I Sangværket 
er det ikke Tilfældet med saa Faae, man kunde ønske at have med, at de ikke kunne synges efter nogen Melodie i vore Choralbøger.

Gid dette Arbeide maa lykkes vel for Dem! Om vi faae Lov til i Kirkerne at bruge Samlingen er uvist; men i Grunden raader dog hverken Bispen eller Cancelliet for, om det skal skee eller ikke. Vor Herre $ø n s k e r$ os det godt; men om Tiden nu er kommet, om Menigheden nu vil bruge, ei misbruge, Hans kostelige Gave, det veed kun Han, og i Hans Hænder bør vi sætte denne, som al vor Sag. Dog ville vi haabe det Bedste.

Der var jo alt Noget vundet om vi fik Bispens Tillæg til det vi har; men det er tydeligt nok, at blev dette befalet indført, kunde det let komme til at staae i Veien for noget Bedre, og Udsigterne rykke længer ud til at Menigheden kunne faae hvad den nødvendig maa savne, alt som den vaagner. Herren veilede Dem og give Dem at vælge det Rette og styre dette vigtige Anliggende efter sin velbehagelige Villie! Ferdinand og jeg ville jo gjerne meddele vort Skjøn, kun at det vil kunne være Dem til Nytte; og med største Beredvillighed tage vi vor Deel i de Bekostninger som rimeligviis vil flyde af, at Samlingen bliver til saa billig Pris, som den bør være, naar ogsaa fattig Folk skal kunne faae den i Hænde, uden at det bliver trykkende for dem, og jeg for min Deel, tager gjerne en dobbelt Portion i Udgifterne, dersom derved Sagen kunde fremmes.

I denne Uge haaber jeg, som sagt, at De atter skal høre fra os. Augusta og Børnene ere ved god Helbred. De og Deres hilses venligst fra Deres taknemlig hengivne

P. Fenger.

(Fengernes Psalmeliste Marts 1843:)

\section{Advent}

Fryd Dig Du Christi Brud.

Op glædes Alle, glædes nu.

(Sangværket)

Søde Jesu Davids Rod.

(Kingo)

(Hagen)

Glæd Dig Zion, glæd Dig Jord.

(Ingemann) 


\section{Juul}

Et Barn er født i Bethlehem.

Et lidet Barn saa lystelig.

Lovet være Du Jesu Christ.

Fra Himlen kom en Engel klar.

$\mathrm{Nu}$ Bod vi fik for Synd og Død.

Lov og Tak og evig Ære.

Vær trøstig Zion, Jesu Brud.

I denne søde Juletid.

Hvordan takke vi Vorherre.

Et helligt Liv, en salig Død.

Jeg som et Barn mig glæde vil.
(Sangværket)

(do.)

(L. do.) (Gaar paa Svenn Vonveds Vise)

(L. do.)

(Bruun. Sangværket)

(Kingo, med Tillæg af Verset:

Tak for al Din Fødsels Glæde)

(K. som i Sangværket Pag.

73)

(Brorson)

(do.)

(Hagen)

(Ingemann)

\section{Nyt-Aar}

Lad Dit Rige allevegne.

Kom Hjerte tag dit Regnebredt.
(Brorson, med Udeladelse af v. 4. 5. 6. 7.)

(do, v. 5 udelades).

\section{Fastelavn. Daaben}

Enhver som troer og bliver døbt.

$\mathrm{Nu}$ bør ei Synden mere.

Kommer hid kun med de Smaa

O lad Din Aand nu med os være.
(Kingo).

(Kingo).

(Sangværket. NB har ingen Melodie. Der mangler en Linie, ellers kunde den gaae som: Frygt mit Barn den sande Gud). (gjentages næst sidste Linie, gaaer det an at synge den paa den Melodie og det kan tilkjendegives ved dette Tegn :/:).

(Sangværket. NB til denne er eiheller Melodie. Men vi behøve saadan en Psalme til Barnedaab). 


\section{Skjærtorsdag. Nadveren}

De tre sidste Vers af:

Fra Herrens egen Mund og Ord. (som de fimdes i Hagen)

O Jesu søde Jesu Dig.

Vor Frelser ved Dit Naadebord.

Mindes vi en fuldtro Ven.

Aldrig kan jeg sige. (Hagen).

(Mel: jeg veed et evigt Himmerig. Sangværket)

Jesu din søde Forening at smage.

(Mel: Jesus han er Syndres Ven. Sangværket). (Brorson).

(Pontopp. Psb. Hygom)

\section{Langfredag. Passionen}

Hører til I høie Himle.

Ingen Høihed ingen Ære.

Gak under Jesu Kors at staae.

Følger med til Urtegaarden.

Den bittre Død Dig trængde.

Solen vel i sorte Klæder v.1 og 4.

Ømme Taarer, Hjerte Toner. (som i Hagen)

(Hagen, dog, jeg beder saa

kjønt jeg kan, lad det sidste Vers være som Kingos eget).

(Hagen).

(S. Mel: Medens vi i Verden vanke, el.: Himlens Gud og Jordens).

(S. Mel. O Jesu for Din Pine). (S. Mel: Nu velan).

(Bruun. S. Mel. Jesu Dine dybe Vunder).

\section{Paaske}

Op Sjæl, bryd Søvnen af.

Som den gyldne Soel.

Hvor lifligt er det dog at gaae.

I Døden Jesus blunded.

Lyse Morgen er oprundet.

Hørt det har jeg Han opstod.

Hvad er dog Paaske sød og blid. (som i Hagen, v.5 efter Sangværket)

(som Kingos eget)

(Hagen)

(Jonæson)

(Ingemann)

(do)

(Brorson) 
Hører I, som græde.

Tag det sorte Kors fra Graven.

Nu ringer alle Klokker mod Sky. (do. som i Sangvarket. Mel. Jesu Du min Glæde)

(Hagen)

(Ingemann)

\section{Himmelfart}

Min Sjæl og Aand opmuntre Dig.

Drag Jesu mig.

Høitidsdagen Høitids Gangen.
(Kingo)

(Hagen)

(S. NB. dertil kjende vi ingen Melodie)

\section{Pintse}

$\mathrm{Nu}$ rinder op vor Pintsefest.

Gud Hellig Aand i Troe os lær.

Hellig Aand vor Sorg Du slukke.

$\mathrm{Nu}$ bede vi den Hellig-Aand.

Aand over Aander kom ned.

Fra Himlen Herrens Aand nedfoer.

Guddoms Straale, Himmellue.

Guds Kirke er saa fast en Borg.

Kirken er som Himmerige.

O Hellig-Aand Du Skat saa skjøn.

Som Hønen klukker mindelig.

Frygt mit Barn den sande Gud.

Hvor deilig skal Guds Kirke staae.

Søde Jesu vi er her.

Din Aand o Gud har ført Dit Ord.

Min Sjæl om Du vil nogen Tid.

O Sjæle-Hyrde Gud og Mand.

Op al den Ting som Gud har gjort.

Gud skal Alting mage.
(Hagen)

(Kingos Psalmebog)

(S. Mel: Medens vi i Verden).

(S.)

(Bruun. S. Mel. Jesu Din søde

Forening at smage)

(Ingemann)

(Brorson)

(Hagen)

(S. Mel: o sa[n]ctissima)

(Jonæson)

(S. (Mel: Hvad kan os komme til eller Af Dybsens Nød etc.))

(Hagen)

(Kingo)

(Pontoppidan)

(S.)

(Kingo)

(do.)

(Hagen)

(Brorson v. 3 udslettes) 
De 3 sidste Vers af:

Hører Verdens Øer hører.

Du bør o Jesu have.

Jeg gaaer i Fare hvor jeg gaaer.

Vær i Korset tro og stille.

(Kingo)

(sidste Vers af: saa skal dog Satans Rige, Kingo)

(Brorson)

Sørger Du endnu min Sjæl.

Lover den Herre, den mægtige Konge. (Pontoppidans Psb.)

Dersom der optages Sange uden bekjendt Melodie, bede vi for: »O store Gud vi love Dig."

Hos Herren paa det Høie.

O kjære Sjæl frygt aldrig meer.

Sørger ei for dem som sove.

(S. Mel: O Jesu for Din Pine) (Kingo)

(S. Mel. Død jeg venter dig)

(I 1st Vers: »Høitids-Færd»

for: »Gildes-Færd.«)

Til P. Fenger ${ }^{6}$

Kiære Ven!

Khvn. 4de Marts 1843

Tak for Brevet og for Psalmelisten fra Brødrene, som er mig til megen Oplysning, skiøndt jeg naturligviis ikke kan være enig med Dem om Alt, og allermindst om Brorsons Overscettelser af Tydsk og mine egne af Engelsk, som neppe i en heel Psalmebog og aldrig i et Udvalg kan komme i Betragtning.

Hvad de Ingeman[n]ske Psalmer angaaer, da maa jeg spørge: er de prøvede hos Folket og har fundet særdeles Yndest? thi ellers tør jeg ikke vælge dem til Kirke-Psalmer, da de sjelden gaae dybt i det Christelige, men har tit smaa Anstødsstene baade i Ord og Tanker, som han ikke holder af, man vil rette.

For Resten vil allerede Rummet byde, hvad jeg ogsaa troer, i det Hele er godt, at forkorte de ældre Psalmer, thi skal Samlingen nogenlunde raade Bod paa det Savn, jeg baade som Præst og Christen føler, maae vi have Noget af mange gamle Psalmer og endeel Nye, saa det giælder om hvad der har »Saft og Kraft«. For at giøre min Mening tydelig, tilføier jeg, at »I denne søde Juletid « bliver her kun fire Vers 1. 5. 3. og 7. »Velkommen igien Guds Engle smaa« bliver fem 1. 4. 5. 6. 7. 
og af alle Kingos Passjons-Psalmer (undtagen: »Hører til« og »Ingen Høihed «) har jeg sammensat $T o$, hver paa 9 Vers, hvori jeg haaber at have samlet hvad der mest savnedes. De skal derfor have Tak, om De vil nævne mig Flere, især af den Kingoske Kirke-Psalmebog, som har staaet sin Prøve og maa nødvendig have langt flere gode Venner paa Marken, end de der nu kiende den. Mangt et enkelt Vers kiender og optager jeg, men Mange kan have undgaaet mig, og efter min Erfaring er det dog egenlig saadanne smaa Guds Engle, der ledsage os!

»Kommer hid kun med de Smaa« har jeg, efter Deres Raad givet en Linie til i hvert Vers, men ladt den ærlig bøde for det i Længden, saa der bliver kun 3 Vers 1. 5. og 7. Derimod har jeg kalfatret den "Var Vandet alene« 1. 2. 3. og 6. saa den kan synges som Brorsons »Vær trøstig mit Hjerte, bedrøv dig ei meer«. Kiender De den Tone? Det gamle "vore Øine see aleneste Vand « maatte endelig have sit Udtryk. Til Confirmationen har jeg skrevet to Nye, den Ene til Mel. »Hjelp Gud at jeg nu kunde, « som vel er temmelig glemt, men skal være smuk, og kan, efter Faldet, være det. »Enhver som troer« optager jeg efter Kingo, blot med lidt Sprogrettelse.

"Gud Helligaand i Tro os lær« vilde De have som hos Kingo selv, men det er vist kun i Sammenligning med den hos Hagen, thi i Sangværket er det Gamle vist skedt sin Ret, thi vel har jeg ogsaa en gammel Kiærlighed til Udtrykket »udi hans dybe Vunder « men her maa dog nok det Klare foretrækkes som det Sikkreste.

Til »Nu bede vi den Helligaand « vilde jeg gierne have »Klippen er Christus « til Omkvæd istedenfor det gamle »Kyrie eleis « men gaaer det slet ikke an, kan det ikke da forlænges til »Klippen det er Christus«, som »Kyrie eleison? « Maa det imidlertid opgives, vil jeg sige »Ja, i Jesu Navn« som maa slaae til.

Dog, saaledes kunde jeg blive længe ved, og har dog alt sagt Nok, for at De kan see, jeg sidder midt i det, og Andet var det i Grunden ei, jeg vilde sige, thi hvad Vorherre fører os ind $i$, det fører Han os ogsaa vel ud af, naar vi kun troe Ham til det, og da Han nu har gjort mig ivrig paa at faae lidt bedre Kirkesang, troer jeg ogsaa, Han vil indføre den, hvem der saa end holder paa Kirkedørren, for hvad Han vil, det vil Han.

Kiærligst Hilsen fra os alle, som De ogsaa ved Leilighed vil meddele Broder Ferdinand!

Deres Ven

N. F. S. Grundtvig 
Fra P. Fenger ${ }^{7}$

Kiære Hr. Grundtvig!

Slotsbjergbye d. 9. Marts 1843.

Hvorvidt Deres Oversættelser af Engelsk, fortjener Navn af Oversœettelser, det kan jeg ikke have nogen Mening om, da jeg desto værre er aldeles ukyndig i det engelske Sprog. Kun det veed jeg at stundom er Deres Omarbeidelser og Oversættelser at ansee som egne Psalmer, hvortil De kun tager Tonen eller Anslaget af den ældre Ps. (f. Ex. Vor Jesus kan ei noget Herberg finde, Brorson, S: Pag 431 o.m.fl.), og det har syntes mig, at mange af de Ps., De har givet af eller efter det Engelske, have et saa kirkeligt Præg, og ere saa smukke, at det var Synd de skulde lukkes ude allesammen fordi de ere af engelsk Herkomst. Der er dog sagtens angelsachsisk Blod i Nogle af dem. Blandt Brorsons Oversættelser ere der nogle, som finde stor Yndest hos Folket. Dog - er der saa meget Fortrinligt, at det ikke kan komme med, saa er det jo rimeligt at hvad der er Oversættelse maa vige for de originale, det er at antage, at hvad der oprindelig er udsprunget paa vort Tungemaal, maa ligge vort Hjerte nærmest.

Hvad Ingemanns Ps. angaaer, ere vel Enkelte prøvede og have fundet Yndest; men "scerdeles Yndest" kan jeg ikke sige jeg har erfaret at de have fundet. Saa hvad der har bevæget mig til at sætte dem med paa Listen er tildeels Hensyn til, at der ogsaa $i$ en ny Ps.bog burde tages Hensyn til hvad »dannede» Folk ynde, og at I., om end det Christelige ikke gaaer dybt, har sjunget saa christeligt, og leveret saa mange aandelige Sange, at jeg tænkte Vorherre vilde ogsaa have, at Nogle af vor kjære I. ogsaa skulde tages med.

Af Brorsons: »I denne søde Juletid" vilde jeg bede for v. 6 som jeg veed scerdeles har tiltalt og trøstet Folk. Naar dette Vers kom efter v. 3 hvori der jubles, og efterat der i v. 5 har været sagt at »al vor Kummer farer bort, " saa kunde det vel synes at Klagetonen ikke skulde melde sig igjen. Men er det dog ikke saa, at der er Bølgegang, ogsaa i Jule-Glæden, og at det er gjennem det tilbagevendende Veemodige at Glæden bryder igjennem til Seier?

Melodien til: „Vær trøstig mit Hjerte« er kjendt og yndet. Psalmen er blandt dem, der baade for Tonens og Indholdets Skyld ofte begjæres i vores »Aftensang $"$.

Melodien: »Hjælp Gud at jeg nu kunde« er en af de lifligste veemodige Psalmetoner, jeg kjender. Vi have iøvrigt en Psalme i den Ev. 
Psb. nemlig No 154, som gaaer paa den Melodie, og hvorved denne Melodie uden Tvivl er bevaret i Erindringen paa mangt et Sted, hvor den ellers vilde være glemt. Vil De høre den kunde De jo i denne Fastetid lade den synge i Kirken.

Jeg tilstaaer Dem at »Gud Helligaand i Tro os lær« i Sangværket har skedt sin Ret. Men Aarsagen hvorfor jeg satte: »Kingo« ved denne er: at, da jeg var ifærd med Catechismen, og talede med mine Venner om, at jeg fandt den Forandring: »I Jesu Liv den Frelse faae, Hans Død os dyrt fortjente« saa fortrinlig, at jeg vilde sætte det istedetfor: »udi Hans dybe Vunder« fandt jeg saa stærk Modsigelse, (ikke at man jo tilstod at Tanken var klarere udtrykt, men fordi man elskede det Tilvante, »udi Hans dybe Vunder«, saa høit) at jeg nødtes til at give efter. Vist er det, at der neppe er nogen Psalme, som Folk saa almindeligt kan udenad, som denne, og den bliver derved næsten som en Øiesteen at røre ved. For mit Vedkommende skulde jeg Intet have imod, men foretrække, Deres Forandringer i Sangværket. Dog at jeg i sidste Linie skulde foretrække: »i evig Roe« for: »i Himmerig«; maaskee som en Følge af, at min Aand ved dette Udtryk saa ofte er vederqvæget.

Omqvædet til »Nu bede vi den Helligaand « kan ikke godt bruges efter den nu almindelige Melodie naar det kom til at hedde: »Klippen er Christus. « »Ja i Jesu Navn« passer bedre. Iøvrigt er der i 2 den Linie, som den er i Sangværket kun 7 Stavelser istedetfor at der er 10 som den er i den Ev. Psb. og der maatte vel saaledes alligevel gjøres nogen Forandring i Choralbogen ved denne lidet bekjendte og noget vanskelige Melodie. Vi have dog, ved at lade nogle Toner ude, sunget den som den er i Sangværket efter den sædvanlige Melodie.

Kunde det lykkes mig at pege paa En eller Anden af de »smaae Guds Engle«, som var sluppet fra Dem, vilde det jo være mig kjært. Jeg skal see mig om efter dem en af Dagene, thi idag vil Tiden ikke strække til, og naar det er skeet sende Dem nogle Linier.

Gud velsigne Dem og Deres Gjerning i Jesu Navn! Det ønsker og beder af Hjertet Deres taknemlig hengivne

P. Fenger. 


\section{Til P. Fenger ${ }^{8}$}

\section{Kiære Ven!}

Khvn. 11te Marts 1843.

Tak for Brevet og Tak for Løftet, som jeg venter snart opfyldt, mens jeg er i Aande med Arbeidet, og hvad jeg bad om, var en Liste paa andre Gamle, som huede og paa dem i Sangværket, De havde fundet Tone til og Lyst til at synge. - Idag fik jeg endelig Rørdams Liste, hvorpaa der findes en heel Deel af de Sidste, men tit staaer der enten slet ikke paa hvad Melodi, eller jeg henvises til en Kæmpevise, der kan være godt nok, men er dog her ubrugeligt. Deres Henvisning til »sanctissima« ved »Kirken er som Himmerige«, siger vel Theodor er ganske efterrettelig, men Bojsen kunde dog ikke synge den derefter, saa der maa dog nok giøres lidt Forandring derved, ikke Enhver falder paa.

Ved »G. Hd. i Tro os lær« har De Ret i at »evig Ro« skal ind igien, men »dybe Vunder" som i denne Sammenhæng er uforsvarlig smagløst, kan jeg ikke optage. Det er nemlig et af de Vers, som er daglig i min Mund, ved Bearbeidelsen til Hagen følde jeg saa bestemt, at det Udtryk maatte bort, at jeg endog foretrak det matte. Det Sidste ankede jeg imidlertid hele Aar paa hos mig selv, til det faldt mig ind, som staaer i Sangværket, og dermed har jeg siden befundet mig vel, saa det Udtryk har en heel Historie i mit eget Liv, der nødvendig overveier Andres Skiøn, som jeg ikke kan vurdere. Da jeg imidlertid, som før sagt, selv fra gammel Tid har holdt af »dybe Vunder" som paa passende Sted, skiøndt ikke ret dansk, har noget særdeles varmt, saa prøvede jeg begge Dele igien og fandt, at $L i v$, som Udtryk, i Sammenligning var koldt og besluttede at sættte »Favn« isteden, saa Verset kommer til at lyde: Gud Helligaand i Tro os lær vor Frelsermand alene af Hjertet ret at have kiær og hannem saa at tjene, at vi fra Dødens Grumhed maae i Jesu Favn den Redning faae, hans Død os dyrt fortjende!

Saavidt jeg endnu har kunnet skiønne, bliver min Liste for Kirken, Daaben, Confirmationen og Nadveren følgende: $\mathrm{Nu}$ bede vi den Helligaand (som er rettet efter Ps.bgn.) Den hellige Kirke kaldes ret (med 5 Vers til af »Den hellige Ks. skiønne Navn«), Var Gud ei med os nutildags (paany fordansket efter Luther), Guds Kirke er vor Klippeborg (læmpet mere efter Luthers), Kirken er som Himmerige, Hvor deilig skal Guds Kirke staae (1. 2. og 7. V.), O kiære Sjæl frygt aldrig meer (V. 1. 2. 4. 6. 8. og 9. lidt forandrede). 
Kommer hid kun med de Smaa, Var Vandet alene med Menneskebud, Enhver som troer og bliver døbt (efter en ældre Bearbeidelse, ført saa noer til Kingos, som jeg kunde), Frygt mit Barn den sande Gud (som hos Hagen, kun med det gl. »Brød os giv« og »med dit Blods den klare Vin « i sidste Vers), Løgnens Fader vi forsage (ny paa $4 \mathrm{~V}$. som: Jesu dine dybe Vunder eller Lov og Tak og evig Ære), Velkommen Morgenrøde, Til Salighedens Dag (ny paa 4 V. som Hjelp Gud at jeg nu kunde, men denne skulde havt en munter Tone), Over Vandet Herrens Røst (ny paa 4 V. efter Math. 28 som: Mit Barn frygt etc.), Nu bør ei Synden mere (hvoraf jeg dog kun kunde bruge V. 1. 2. og 5. temmelig forandrede).

Jesus din søde Forening at smage (fandt jeg ved nøiere Giennemsyn saa lidt en Altergangs-Psalme og i det Hele saa mystisk vild, at jeg helst havde udeladt det Hele, men da jeg formoder det hos Christne er især de første Ord og enkelte i Resten, der har trukket, saa har jeg til den gamle Begyndelse sammenplukket to taalelige Vers), Gaaer det Herre, som jeg vil (3 V. af: Smuler under Herrens Bord, som jeg vel ikke veed Tone til, men veed har været sunget, findes ogsaa paa Rds. Liste), Herre hvor skal vi gaae hen (V. 1.4 og 8), O Jesus, søde Jesus dig, (men 2det V. maa hedde: Bryd ud min Sjæl med Fryd og siig: O hvor er jeg nu blevet rig! Min Jesus i mit Hjerte boer, Et Himmerig det er paa Jord, thi »Tak, Tak, hvad er min Glæde stor« er kun en mat Efterklang af 1ste Vers), Jesus Christus Livets Drot (ny over Indstiftelsens Ord paa 3 V. og gaaer som: Mit Barn), Jesu søde Hukommelse (nyt bearbeidet efter den Latinske).

Siig mig nu Deres Mening herom! thi vel kan jeg ikke love at følge mine Venners Mening, men tage den alvorlig i Betragtning og see til med Guds Hjelp at følge det Bedste, det vil jeg ved denne Leilighed ret inderlig gierne, da det nødvendig maa ringe for mit Øre hvad saa tit bevægede mit Hjerte - Dens Tjenere har Lyst og stor Behag i hendes Bygnings Steen, ja det var deres Hjerte-Trøst at Herrens H[uus] det kom igien paa Been, thi de har Medynk over dens Foragt, at Herrens hellig Huus i Støv er lagt!

Det faldt mig først ind igaar, at vi burde dog have lidt til Barnedaaben med Herrens Ord »Af Diendes og Spædes Mund» og da jeg fandt, de gik som »Enhver som troer og bliver døbt« skrev jeg 3 Vers, hvoraf især det Sidste endnu idag staaer mig saa godt an, at jeg troer, det kan ogsaa tækkes Dem imorgen, saalydende: Vi døbe dem i Jesu Navn, vi tør dem ei forhindre, vi lægge dem i Jesu Favn, de kan ei blive mindre, 
o lad dem voxe ved Hans Bryst, og lad dem frydes ved Hans Røst, saa deres Øine tindre!

$\mathrm{Nu}$, Herren befalet! hils kiærligst fra os alle!

\title{
Deres Ven
}

Grundtvig.

\author{
Fra P. Fenger ${ }^{9}$
}

Kiære Hr. Grundtvig!

Slotsbjergbye d. 13. Marts 1843

$\mathrm{Nu}$ har jeg da endelig faaet Mynsters »Udkast« som jeg hidtil kun kjendte det til, som Andre havde sagt mig. Den Mand forstaaer jeg mig ikke paa. Han vil dog have: Gud Hellig Aand i Tro os lær, O Hellig Aand, du Skat saa skjøn, Nu rinder op vor Pintsefest, Vi troe paa Dig Du Hellig Aand, han tør nok sætte i Psb. "Synd og Død og alle Pile, Som af Satan skydes kan«, Og »bed at Gud for Jesu Blod Vil lade sig forsone «, »At Helvede skal skjælve ved « og andre Udtryk, som han dog maa vide at Clausen (vel sagtens ogsaa Rosenvinge) vil spytte ad, og dog holder han snarere Broderskab med dem end med os! Det er mig næsten en ubegribelig Forblindelse. Dog vi skulle ikke begribe alt hvad der kan falde os ind at spørge om, vi skulle ikke dømme. Herren bevare aleneste os, at vi ikke, idet vi søge vort Eget, skulde være Skyld i at saadan Adskillelse skal vedblive eller blive endnu større, saalænge vi ikke kunne nægte, at det er den Troe til Salighed, som er de Christnes, han forkynder. - Om hans Arbeide derimod tør man vel dømme, efter bedste Indsigt, og jeg kan rigtignok ikke see Andet, end at det er ubegribelig maadeligt udført. Hvor kan han dog troe at hvad Christne mest maae savne af ældre og nyere Ps. skulde indeholdes i dette Udkast? Hvad er det dog (som Ingemann engang sagde om Wexels Forandringer ved de af ham optagne Ps.) for et Lappe-Skrædderie han har tilladt sig med afdøde og endnu levende Digteres Arbeider! At han har brugt Sangværket sees af hans Redaction af »Frygt min Sjæl den sande Gud», (hvori han, skjøndt han pløier med Deres Kalv, dog vil makke selv) thi hvorfor har han ellers: "Vederqvæg mig Frelser god Med Livs-Kalken i dit Blod" det har han ikke af sig selv, - og dog har han kun deraf fundet een, siger og skriver een Psalme, at optage. Brorson har han flest af; men dog kan han med Udeladelse af saa mange andre Fortrinlige 
optage en halvmaadelig Oversættelse af Br. og endda kludre paa den $\mathrm{f}$. Ex.: "Vor Sjæl er dertil fød og baaren«. Af Boye savnes vist ikke Meget i Kirken. Det maa han dog have antaget. Og hvad Forstand kan Mynster have paa Kirkesang naar han optager Timms »Træd frem min Sjæl«. Mon han har tænkt sig hvordan det vilde tage sig ud naar Menigheden sang: »Hvad haaber du? Blandt Dine længer at leve virkende for dem? $\mathrm{Nu}$, det er skjønt, « etc. Nei det er virkelig ikke skjønt at indføre, eller ville indføre, saadanne Hverdags-Dialoger i de Christnes Chorsang i Kirken.

Dog, lad mig bryde af. At mit Ønske om at Deres Arbeide maa lykkes og finde Bifald, og Indgang i Helligdommen, ikke er aftaget men tiltaget ved at læse M.s Udkast, vil De, uden min Forsikkring, antage.

»Kirken er som Himmerige« gaaer virkelig godt efter »o sanctissima« hvad saa end Boisen siger, thi det er prøvet og godt befundet. Jeg hensætter Oplysning derom:

Kir - ken er som Him - me - ri - ge

O sanc-tissi-ma, o pi - issi - ma

Me - get kan den lig - nes ved

Dul - cis vir - go Ma - ri - a

Skjøndt paa Jord den har ei Li - ge

Ma - ter a - ma - ta in - teme - ra - ta

Som Guds Naa - de og Guds Fred

O - ra, o - ra pro no - bis!

Jeg er godt fornøiet med »i Jesu Favn«, og vilde kun foreslaae: »Frelse« for $»$ Redning « fordi mig synes det klinger bedre. Give Riimbogstaver Velklang ved Vers som læses, da give de ikke mindre naar de synges. Det kom altsaa til at hedde: "at vi fra Dødens Grumhed maae i Jesu Favn den Frelse faae, Hans Død os dyrt fortjente«.

»Den hellige Kirke kaldes ret« kan synges efter: Allene Gud i Himmerig.

(O Gud give dog at vi maae komme til at synge saaledes i Herrens Huus! da vil det vist inderligere end det har gjort længe komme til at 
tone i Menighedens Bryst: »hvor liflige ere Dine Boliger Herre Zebaoth etc $\ll)$.

Efter hvilken Melodie gaaer: „Var Vandet alene«?

At De udelader: »Jesu Din søde Forening « maa jeg ved nøiere Eftertanke billige aldeles, thi det er ikke tænkeligt at den skulde kunne være Udtryk for (selv den christeligste) hele Menighedens Stemning, og man skulde ei give den samlede Menighed Noget at synge, som ikke Alle af Hjertet kunne synge med! Men da Psalmen iøvrigt er saa usigelig dyrebar for mange Enkelte i Menigheden, der under Kamp og Anfægtelse deri have fundet et Udtryk for deres Stemning, vilde jeg heller raade til heelt at udelade den, end at sammensætte Noget deraf, som vanskelig vil tilfredsstille de Mange, som kjende og ynde den Gamle. Tonen er desuden for vanskelig til en Kirkemelodie, den læres vanskelig endog af dem der ellers har Øre for Musik, jeg har hørt den synges efter en bekjendt Menuet-Melodie.

Det er saa fornøieligt for mig at høre at De har valgt Verset: „Gaaer det Herre som jeg vil«, det var en af de Engle jeg havde faaet Øie paa, og han hjalp mig igaar i min Prædiken. Men jeg tilstaaer at jeg ikke har fundet nogen bekjendt Melodie, hvorpaa det Vers kan synges. En af de nærmeste er »O hellig Aand vor Bistand vær« No 200 i Ev. Psb. men den passer dog ikke ret.

Til : »Herre hvor skal vi gaae hen « kiender jeg heller ingen Melodi.

Jeg vilde heller have: »det er et Himmerig paa Jord « end »et Himmerig er det paa Jord«; thi efter min Erfaring forstaaes og behager en Psalme desto bedre, jo lettere den er i Ordføiningen. Maaskee ogsaa at det som det staaer hos Hagen alt er bleven mig tilvant og derfor kjært.

Hvad jeg synes om dem De har? Ja jeg kjender jo endnu ikke næsten de halve. Men dem jeg kjender synes jeg saa inderlig godt om. Blot De ikke naar De nu kommer til de øvrige Afsnit skal blive nødt til at tage nogle af dem tilbage for Pladsens Skyld. Bliver det nødvendigt, saa tag heller (ceteris paribus) Nogen af de nye tilbage, end af dem, som alt ere kjendte, prøvede og kjære, og tag heller dem tilbage, som have en vanskelig eller ubekjendt Melodie, end Nogen af dem vi strax kunne synge.

$\mathrm{Nu}$ nogle Vers hvorved Savn kunde udfyldes:

De 2 sidste Vers af: "Nu kom her Bud fra Engle-Chor" (som hos Kingo).

Sidste Vers af: »hvor stor er dog den Glæde«.

De 2 sidste Vers af Hvor saligt var det Ægtepar (der maatte vel ændres noget). 
De 3 sidste Vers af: »o kjære Sjæl luk op din Mund«.

»Herre Jesu Christ min Frelser etc. (den Gamle v 1. 3. 7. 8).

Det sidste Vers, eller lidt mere, forandret af: »om Himmeriges Rige saa ville vi tale."

O Jesu for Din Pine (jeg har engang hørt hos Dem en Bearbeidelse, som jeg syntes saa godt om).

Noget af: " See hvor nu Jesus træder«.

- $\quad$ "Naar jeg betænker den Tid og Stund $\ll$.

- $\quad$ " $\quad$ Med Sorgen og Klagen hold Maade«.

De 4 første Vers af »Optagen er i Herlighed« (Mel: Kommer til mig etc. Sangværket Pag 502 Hlfart.)

10de og 11 Vers af Korsets hvide Seiersfane (Mel: Død jeg venter Dig med Længsel eller Jesus er mit Liv i Live etc. Sangværket Pag 653.) Hos Ferdinand synges der mere af Kingos gl. Psb. end her. Lad ham nævne hvad der hos ham er meest i Gang. Jeg skal sige det til ham paa Torsdag. Farvel! Guds Fred! Deres

\section{P. Fenger.}

Til P. Fenger ${ }^{10}$

Kiære Ven!

Khvn. 14 Marts 1843

Tak for Brevet og for den alvorlige Deltagelse i Sagen, som det vidner om!

Redning har jeg valgt med Flid, fordi det mere bestemt og levende hentyder paa Faren og Nøden, og da tillige fordi »Frelse«, som i den næste Linie vilde lyde meget godt, skurrer mellem »Favn« og »faae« som tredie Rimbogstav i een Linie, der er det femte Hjul til en Vogn.

"Var Vandet alene med Menneske-Bud « har jeg anmærket, skal gaae som »Vær trøstig mit Hjerte bedrøv dig ei meer«, som De ogsaa har sagt mig er en brugelig Tone, men for at De kan see, hvordan det lader sig giøre, vil jeg afdele et heelt Vers. 
Det Vandbad i Ordet, som Herren vort Haab Med Almagt omgjordet, gav Navn af sin Daab

Vor Syndighed døder,

Guds Billed gienføder,

Fornyer den Skabning, som kom fra Guds Haand, Indgyder til Livet os Sandhedens Aand!

I Henseende til Valget efter Rum er jeg ganske enig med Dem om, at ved Høitiderne og det egenlig Opbyggelige skal alt Nyt vige for det Gamle, men ikke saa ved Daaben og i det hele ved Kirkens levende Grundvold og Betragtning, thi det var de Gamles svage Side, som trænger høit til ny Understyttelse. Til Lykke gaaer det imidlertid dermed, som med Grundvolden, Herren har lagt som en viis Bygmester, at Rummet den optager, er kun meget lidet, og der at spare paa et Par Blade fristes vi ikke til.

De 2 sidste V. af $» N u$ kom her Bud etc. « er saa som de er, og i alt Fald maatte dog nok 4de L. sidste V. hedde "Skal op til Gud sig skynde« og i forrige $\mathrm{V}$. " $\mathrm{Og}$ aldrig fra dig rygge« ombyttes med lidt Bedre, thi selv naar man faaer Mening i det haartrukne og smagløse Ord, passer det dog slet ikke til »undfange dig«, naar man har mindste levende Betragtning deraf, men den gode Kingo havde det ikke, tænkde ved »undfange « kun »modtage" s som en Giæst og ei vende ham Ryggen.

Sidste V. af »hvor stor er dog d. G. « glemmer jeg vist nok ikke, men det har jeg nu saamange Aar nynnet paa baade for mig selv og med mine Børn, som det staaer hos Hagen, at anderledes kan det ikke komme fra min Haand, undtagen at det i Munden er blevet til »Vor Hjerne selv du vende«, og det er overalt den Hovedfeil hos vore Fædre, vi hos deres Børn maae stræbe at rette, at de hver for sig vilde underhandle med Frelseren og eie ham, hvad ei gaaer an, som blandt andet Fader vor skulde lært dem.

De 2 V. af: hvor saligt er d. Æ. er jeg ikke videre fortrolig med, men naar jeg undtager »Bryst og Liv« har jeg heller intet imod dem.

Versene af »Kiære Sjæl luk op« skal De have Tak for, de bør vist optages.

»Herre Jesu Christ« er mig en gammel god Ven, som jeg gierne seer i sine gamle Klæder, og fremfor Alt er V. 3 mig dyrebart, men jeg havde derfor tænkt at sætte det for sig selv, da det dog seer sært ud i vore Dage med kvindelige Rim, hvor der skulde være mandlige, men for Øiet kan jo en Apostroph giøre godt og Øret har det ingen Nød med. 
»Om Himmeriges Rige« mindes jeg gierne, den er udsprunget af et velsignet troende Hjerte, og de to sidste V. som vel passe ordenligst med Tonen, kan vi godt faae, men den maa jeg tænke mere paa.

»O Jesu for din Pine« har jeg tænkt paa at sætte omtrent heel som "Skrifte-Psalme« og giør det udentvivl.

"See hvor nu Jesus træder« er to Stykker af to deilige Psalmer, men det er Hovedet af den ene og Halen (V. 10-14) af den anden, saa jeg veed endnu ikke, hvad derved er at giøre.

»Naar jeg betænker« og »Med Sorgen og Klagen« staae ogsaa paa min Liste, til at synes og deles paa det bedste.

Tak for Tonen til »Optaget er i Herlighed « men jeg vilde neppe nænne at lade de to sidste Vers blive Stifbørn, da det netop er Gicesterne.

»Korsets hvide Seiersfane« var jeg neppe selv blevet opmærksom paa fra den Side, som jeg finder rimelig nok, kun maatte vel 1ste V. ændret derefter, følge med.

Mel. til »Gaaer det Herre som jeg vil« veed jeg ikke heller, men jeg veed Fru Lindberg hittede strax paa at synge og spille den, og saa gaaer det vel. - »Herre hvor skal vi gaae hen? « staaer hos Bojesen til "Fadervor i Himmerig" og det maa være rigtig.

Kan De slet ikke sige mig nogen Raad til saadanne fire Linier:

Apostlerne sad i Jerusalem

Og bied paa Herrens Time,

For Øren da brat det ringed dem,

Som tusinde Klokker kime.

De maatte kunne synges som de første 4 Linier af »Den signede Dag, som vi nu seer«, men om slig halvveis Sang gaaer an, veed jeg ikke. Hils Broder Ferdinand venligst! Ingemann seer jeg kun lidt til, han har saa travlt som Muus i Barselseng, og naar der kunde fødes et Bjerg i Modsætning til det Romerske mons parturiens var Travlheden velanvendt.

Deres Ven

Grundtvig. 


\section{Fra Ferdinand Fenger ${ }^{11}$}

Kjære Hr. Grundtvig!

Liunge d. 21. Marts 1843

I Torsdags talte jeg med Peter, saae Deres 4 Breve og glædede mig over at De er i fuldt Arbeide. P. har nok skrevet til Dem, at jeg maaskee kunde give Bidrag af enkelte Vers meest i Kingos Psalmebog, der ere Menigmand kjære.

Strax da jeg kom herud i 1833 hørte jeg fra en meget gammel Kones Dødsleie et Vers der lød omtrent saaledes:
Min Ungdoms Brøst og Ufornuft
O Herre Du forgjætte
Forlad mig al min slemme Utugt
Og mine Synder udslette;
Men Jesu Christi Rosensblod,
Som nøgen for mig paa Korset stod
O Herre ihukom dette!

Samme Vers har jeg ofte siden hørt fra Sygesengen, og naar den Syge kom til de 2 sidste Linier saa qvaltes Stemmen stundom af Graad. Jeg er temmelig sikker paa at jeg har seet dette Vers i Kingos Psalmebog, midt inde i en Psalme; men i Dag har jeg ikke kunnet finde det.

Den Psalme: »jeg arme Synder træde maa« er ogsaa Menigheden kjær, især det sidste Vers: "I Brystet er der jo paa Dig en Naadens Springekilde."

Det Vers af Psalmen paa Fastelavns Søndag: »op Hjerte, Hu, op Sjel og Sind «:

O Gud, som Forbund, Fred og Pagt,

Med os i Daaben gjorde

Styrk os mod Satans Vold og Magt

At vi Guds Lemmer vorde o.s.v.

er saa godt kjendt af de Ældre fordi min 3die Formand, gamle Plokros altid brugte det ved Confirmationen.

Husk paa Slutningsverset af: »saa skal da Satans Rige» 
Du bør jo ene have

Mit Hjertes hele Bo

Kom Jesu tag den Gave

Og styrk mig i min Troe!

O Gud mig selv bered

Og aabne saa mit Øre

At jeg Dit Ord maa høre

Min Sjel til Salighed

og paa Begyndelsen af den:

Det Intet krænke skal mit Sind

Om Verden mig vil hade,

Da lukker jeg min Jesus ind

Saa kan mig Intet skade.

Til fornæunte Vers af Kingo: »Du bør jo ene have« svarer et smukt af Brorson:

O Jesu lad Dit Ephata

Mig Mund og Hjerte røre

Saa skal Du et Halleluja

Af begge Dele høre.

$O$ at Dit Broderhjerte maa

I al min Nød mig aabent staae

Saa kan mig Intet fattes.

I øvrigt troer jeg nok at Menighedens fleste Yndlingsvers ville findes i de Psalmer som staae paa Peters og min Liste. For at fremføre een, hvoraf enkelte Vers og navnlig Slutningsversene er meget yndede nævner jeg den: »o Sjele-Hyrde Gud og Mand. «Mange enkelte Yndlingsvers findes jo i Morgen- og Aften-Sangene; men de ville vel ved nærværende Arbeide ikke komme i Betragtning.

Jeg har endnu 2 Ting paa mit Hjerte. De synes tilbøielig til at udelukke Oversættelse baade Brorsons af Tydsk og Deres af Engelsk. Hvad De nu end heri beslutter Dem til, saa er der 2 Oversættelser, som jeg paa egne og Medsangeres Vegne saare nødig vilde savne, nemlig de 2 Julesange: »lovet være Du Jesu Christ « og »fra Himlen kom en Engel klar«. Den første af dem gaaer rigtignok paa en Kæmpevise-Tone; men for ikke at støde Læseren ved at henvise til Svend Vonveds Vise, kan man 
godt sætte »Egen Melodi« da der er en lille Forandring. Den anden gaaer paa »fra Himlen høit komme vi nu her « men vi synge den paa H. 3 Kongers-Tonen. Theodor kan dem begge 2. Dem beder jeg indstændig for, begge 2, ogsaa for det Vers i den sidste, som staaer under Stregen; thi ved det har jeg adskillige Tanker.

Det Andet jeg har paa mit Hjerte er Optagelsen af Ingemannske Sange. De spørger om de er prøvede. Jeg svarer: ja, nogle af dem. »Nu ringer alle Klokker mod Sky« synges her af Unge og Gamle. »Julen har bragt velsignet Bud « (i Kierkegaards Tidsskrift) er ogsaa kjendt; men den kunde jeg ikke engang faae Peter til at optage paa Listen fordi, sagde han, den er for Børn. Men netop derfor vilde jeg have den. Med mange af Ingemanns gaaer det ligesom med mange i Sangværket, der ikke ere prøvede fordi de ikke ere komne ud blandt Folk. Men vi kan saa temmelig i Forveien vide hvad der vil smage dem.

$\mathrm{Nu}$ kun venlig og hjertelig Hilsen til alle Deres fra Folk i Liunge.

Deres tro hengivne

J. F. Fenger

Fra P. Fenger ${ }^{12}$

Kiære Hr. Grundtvig!

Slotsbjergbye d. 23. Marts 1843.

I Torsdags var jeg samlet med Ferdinand, og meddeelte ham Deres Breve, og da jeg ved Samtale med ham erfarede, at der vare nogle Psalmevers af den gl. Kingoske Psalmebog, som ere meget i Brug hos de Gamle henne hos ham og som jeg, saavidt jeg erindrede, ikke havde faaet med, bad jeg ham uopholdeligt at skrive Dem til derom, hvad jeg haaber han har gjort. Derimod har jeg ikke lige uopholdeligt skrevet Dem til, for at besvare det Par Spørgsmaal, der var i Deres sidste Brev, og det gjør mig ondt; thi det kunde synes at røbe Ligegyldighed; men det har det dog ikke været. Jeg havde foresat mig at skrive, men saa kom der usædvanlige og uforudsete Forretninger, og i denne Fastetid er det rigtignok nær ved at gaae over mine svage Kræfter. Jeg har Prædiken og Catechisation i begge Kirker om Onsdagen og saaledes paa en Maade 2 Søndage om Ugen. Confirmander har jeg 2 Gange om Ugen, maa læse 2 til 3 Timer daglig med mine stakkels Børn, og den stadige aandelige Anstrængelse er for mig angribende, især naar der saa kommer andre 
Ting til f. Ex. i Mandags Liigprædiken over Sognefogeden i Sludstrup. Jeg kan ikke synes at det vilde være rigtigt at standse med Prædiken og Catechisation om Onsdagen; thi Kirken, især i Bjergbye, er omtrent fyldt hver Gang, og i Sludstrup er dog, foruden en Deel Ungdom, bestandig en Deel af de Ældre.

$\mathrm{Nu}$ til Deres Brev.

"Var Vandet alene med Menneske-Bud» gaaer fortræffeligt efter »Vær trøstig mit Hjerte bedrøv Dig ei meer.«

Jeg indseer fuldkomment at De maatte vælge nye Psalmer, og bede vor Herre give Dem Naade til at forfatte Nye til det Afsnit om Daaben og om den rette levende Kirke-Grund, saa meget mere, som det i denne Henseende ikke havde klaret sig ret for vore lutherske Fædre. Gud lægge sin Velsignelse dertil. Kjære Hr. Grundtvig! betænkes det hvad Gavn og Glæde Deres Arbeide, naar det lykkes, kan have, ei alene for denne Slægt, men for Slægter, for Børnene efter os, hvad det vil kunne gavne baade i Kirken og i Husene, baade i de Christnes Forsamling og hos den Ensomme paa Sygeleiet, ved Vuggen osv, saa maa vel Hjertet stemmes til at sukke og bede: Herre lad det lykkes nu! Thi Herren har ret tugtet os, men dog ikke givet os i Døden. En ny Morgen oprinder, en Dag som Herren har gjort, skulle vi da ikke fryde og glæde os i den, skulle vi ikke takke Herren og synge Dit Navn Psalmer Du Høieste!

De qvindelige Riim i »Nu vil jeg være, o Jesu kjære etc. « gjør ikke mindste Vanskelighed naar det synges.

»Herre hvor skal jeg gaae hen « synges, i det mindste ikke ifølge de nyere Choralbøger, efter den Melodie: »Fader vor udi Himmerig «. Det kan De overbevise Dem om ved at eftersee i den Ev. Psb. No 532: O Gud, som Alting har frembragt. Den første Stavelse i hver Linie er en kort Stavelse og den begynder med en Optakt. Der mangler en Stavelse i hver Linie, naar Psalmen skulde synges efter Melodien »Fader vor udi Himmerig, « som den nu sædvanlig synges. Derimod naar sidste Linie i hvert Vers blev gjentaget kan den synges som »Frygt mit Barn den sande Gud." Dersom De rettede Noget paa den Psalme vilde jeg foreslaae at Udtrykket i sidste Vers 3die Linie: "Broder fiin« blev ombyttet med et Andet; thi fiin har vist nu i Folkemunde hos os ikke samme Betydning som i gamle Dage f. Ex. i Kæmpeviserne, og som det Engelske fein (saaledes udtales det jo).

Apostlene sad i Jerusalem, kunde De gjerne sætte over: Mel: "Abraham sad i Mamre Lund" thi den synges meget i det mindste hos os, og den synges som en gammel Sang, hvis Omqvæd er: »Roser og 
yndelige Blomme«. Nogen anden bekjendt Tone veed jeg ikke at angive; thi det nytter jo ikke at sige, at den ogsaa kan gaae som »Herr Zinklar drog over salten Hav«. Paa den Tone have Nogle sunget: "Abraham sad i Mamre Lund."

Gid jeg kunde løbe til Dem en Times Tid imellem og høre hvordan det gaaer med Arbeidet. Var det ikke Fastetid med forestaaende Paaske og Confirmation, troer jeg at jeg reiste ind til Kbh. bare for det samme. Men førend om en Maaneds Tid kan jeg af disse og flere Grunde nu slet ikke komme afsted.

Min Kone som i næste Maaned venter sin Nedkomst er dog nogenlunde vel. Alle Børnene ere raske. Hilsen til Dem og Deres fra Deres taknemlig hengivne

\section{Peter Fenger.}

Til P. Fenger ${ }^{13}$

\section{Kiære Ven!}

Khvn 25de Marts 1843

Det glæder mig, De tænker paa at komme herind, thi ogsaa jeg ønskede, naar mit Udkast omtrent er færdigt, at giennemgaae det med Dem og et Par andre Præstelige Venner, som veed hvad der kan synges med Lyst og nogenlunde Lethed, thi næst det at Kirke-Psalmerne skal være indvortes passende, maae de for at være gode til deres Brug udvortes [være] lidt mere end blot syngelige, og derom har jeg ofte kun et svagt og altid kun et dunkelt Skiøn. Vorherre har ogsaa for mig selv allerede velsignet Arbeidet saa rigeligt, at jeg ikke kan tvivle om, Han jo vilde velsigne en lille Forsamling i Hans Navn til at betænke Hans Smaa iblandt os. Busck agter at komme herind engang i Mai, jeg seer, De har tænkt omtrent paa samme Tid, og De kunde da let ved lidt Aftale træffe sammen, maaskee kunde Deres Broder komme med, og da vilde vi i Guds Navn giennemgaae det Hele, som med Hans Hjelp netop til den Tid kan ventes færdigt, og deels overbevise os om, at det $\mathrm{Ny}$, vi byde, kan synges med Lyst, og dels, ved Ham, som vi bede staae midt iblandt os, enes om det Bedste efter Omstændighederne. - Jo længer jeg kommer ind i Arbeidet, des klarere bliver det mig nemlig, at i det Omfang, vi kan give Heftet efter sin Bestemmelse, vil der kun blive lidt Rum til hvad man pleier at kalde det Opbyggelige, det nemlig, som Enhver af os tiest nynner paa for os selv, og helst vil synge med nogle gode Venner; thi Hovedsagen 
er her først Kirken, Daaben og Nadveren, og dernæst vore kirkelige Høitider og kirkelige Forsamlinger i det Hele, og naar kun Øiemedet opnaaes dertil at give en, forholdsviis, god og tilstrækkelig Samling, da er der egenlig Intet tabt ved Mangelen for Resten, thi deels har vi alt Psalmebøger Nok, hvor Enhver har Lov til at vælge hvad der huer ham, og dels kan der altid foranstaltes et Udvalg, til Veiledning for Husandagten, ligesom vi bør have en ny Samling af lutter bibelhistoriske Sange til Børnene. -

Mit Udkast begynder derfor med det reen Christelige: Kirken, Daaben og Nadveren samt Præstevielsen (som ingenlunde maa længer oversees), derpaa Kirkevielse, hvortil jeg har faaet en lille ny Sang, der gaaer som Br.s »Her vil ties«, Brudevielsen, Søndagen Advent, Jul, Fasten, Paaske, Pindse og Ligbegængelse, og da jeg omtrent har giennemført dette til Paasken, kan jeg alt see, det kan kun blive faa hele Psalmer og endeel enkelte Vers, der vil finde Plads, og det maae i Regelen blive saadanne, der have et godt og temmelig enstemmigt Vidnesbyrd fra vor forrige Kirketid. - Om Alt tør jeg vel ikke vente at blive strax enig med mine Venner, men med Guds Hjelp haaber jeg dog at blive det for det meste, og hvad Resten angaaer, vil Gud lade mine christne Venner føle, at jeg har et eget Ansvar for, hvad jeg i mit $60 \mathrm{de}$ Aar byder og anbefaler Herrens Menighed iblandt os, et Ansvar, der baade vil nøde mig til alvorlig Overveielse og til Slutning giøre Udslaget, hvor Tanken og Talen ei er om mindste Tvang men netop om et Valg, vi ønsker maa staae Enhver frit paa eget Ansvar.

"Roser og yndige Blommer" skulde man altid synge med til $\mathrm{Abra}$ hams Vise, naar der hører Omkvæd til Tonen, thi et bedre kunde den neppe faae. -

Hvad jeg for Øieblikket tænker paa, er hvordan en »evangelisk Rimstok « for vor Tid bedst kunde indrettes, thi til noget Saadant trænges altid. En Begyndelse har jeg gjort med endeel af Versene i Sangværkets "Gud taler saa det skeer«, som jeg i min Forlegenhed har faaet til at gaae ganske ordenlig, som »Fryd dig du Christi Brud« med Omkvædet »Paa alle Tunger gløde Guds Ord det evig søde«.

Deres Betænkelighed ved »fiin« kan jeg slet ikke dele, blandt Andet fordi det endnu klinger i mit Øre fra Barnedagene »En liden Søn baade faur og fiin, Han vilde være Lyst og Glæden din."

$\mathrm{Nu}$, Herren give Lykke til det Forestaaende i sit Huus og vores, og hils kiærligst i Deres fra os alle!

Deres

Grundtvig. 
Fra P. Fenger ${ }^{14}$

Kiære Hr. Grundtvig!

Slotsbjergbye d. 3die Mai 1843.

Idag otte Dage, den 26. April fødte min Kone et velskabt Pigebarn. Alt er hidtil gaaet saare vel, og jeg haaber, at min Kone om et Par Dage vil kunne begynde at komme op. Vor Herre bliver ved at velsigne os, ja overøse os med sine Velgjerninger. Børn er jo Herrens Arv. Vi have nu 2 Drenge og 5 Piger, og hidtil Ingen mistet af dem, Gud gav os. Gid Ingen maa mistes evindelig! Det daglige Brød er ikke formindsket, tværtimod formeret, alt som Børneflokken forøgedes. Men som Børnene voxe til mærkes det ogsaa her stedse mere tydeligt, ")at Mennesket lever ikke af Brød alene. « Guds Ord er udgaaet over de 6 af dem, da de døbtes i Jesu Navn. Men de skulle opdrages i Tugt og Herrens Formaning. Dertil hører Viisdom og Forstand. Den give Gud! og det vil Han, alt som Jacob skriver: »dersom Nogen af Eder fattes Viisdom, han bede af Gud, som giver Alle gjerne, og bebreider ikke, saa skal den gives ham; men han bede i Troen."

$\mathrm{Da}$ der nu er Sandsynlighed for, at jeg snart tør forlade min Kone, minder jeg om vor Aftale, at jeg skulde reise til Kjøbenhavn, for at vi kunde tale sammen om Psalme-Sangen. Ferdinand vil ogsaa være følgagtig naar De bestemmer at vi skulde komme, og til Busck skal jeg skrive derom saasnart De lader mig vide, naar det synes Dem meest beqvemt at vi samledes. Dog maa jeg bemærke, at bliver det i Mai synes vi at det ikke godt gaaer an at blive en Søndag borte hjemme fra. Vi vilde da komme ind en Mandag og tage ud igjen næste Fredag med Dagvognen. Blev det derimod tids nok i Juni kunde vi bedre tage lidt længer Tid. Thi min Broder Christian agter at holde Bryllup i Juni, og En af os kommer sagtens til at vie ham, og den Anden vil jo gjerne, om det lader sig gjøre, komme med til Brylluppet. Lod det sig nu gjøre at forene begge Dele, saa baade Forhandlingerne om Psalmerne og Brylluppet kunde afgjøres med een Kjøbenhavnsreise, var det jo beqvemmere for os, og da kunde vi ogsaa gjøre Opholdet i Kbh. noget længer. Men hvis De er rykket saa langt frem med Arbeidet, at Trykningen snart kunde begynde, indsee vi fuldt vel, at der ikke bør skee Opsættelse. Jeg tør da nok bede Dem om ved et Par Ord at lade mig vide, naar De ønsker at vi skulle komme, og dersom dette er saa snart, at der ikke kan blive Tid for mig til at correspondere med Busck (thi Postgangen mellem ham og mig gaaer langsomt, saavidt jeg veed over Roeskilde) vilde 
jeg bede Dem skrive ham til. Jeg haaber at kunne komme hvilken Uge De bestemmer.

Deres Kone vil glæde sig med os over at Alt er vel overstaaet og at vi har Pigen. En venlig Hilsen til hende og Tante Jane og Deres Sønner fra Deres taknemlig hengivne

P. Fenger

Til P. Fenger ${ }^{15}$

Kiære Ven!

Khv. 6te Mai 1843

Til Lykke med den lille Datter og alle de Smaa, som Herren indslutte i deres Tal, der skal arve Guds Rige! Ved at confirmere Meta forleden Søndag følde jeg ret, at selv i levende Live og selv med Hensyn paa vore egne Børn maae vi sige med Paulus: vi overlade eder til Gud og Hans Naades Ord, som er mægtigt til at give eder Arv med de Hellige; thi vil vi have Fingre deri, fordærve vi kun hvad der hos Herren er i de bedste Hænder, naar vi kun ikke skiødesløs smide, men troende og ydmyge lægge det deri.

Pludselig og ganske uventet har Dronningen tilbudt mig en Engelands-Reise i Sommer, som jeg inderlig ønskede, men ansaae for umuelig, og det vil jo foraarsage Ophold med den lille Psalmebog, men da mit Udkast til den er næsten færdigt, haaber jeg dog at kunne levere det til Deres Broder Theodor i den Stand, at De og Ferdinand ved Leilighed kan see hvordan jeg mener det og har faaet Held til at fremme Værket, og at det, under alle Omstændigheder, nedlagt i Deres Haand, kan giøre sin Nytte. - Det er en rar lille Bog, Birchedal har skrevet om Kirkeaarets Evangelier, den maa De endelig læse og lægge paa Hjerte; den har ikke blot glædet mig, men givet mig et klarere Overblik over Sammenhængen i vor Gudsdyrkelse, og de christelige Udviklings-Trin, der ogsaa bør blive staaende i Kirke-Psalmerne, saa nu sætter jeg »Jesu dybe Vunder" ind igien $\mathrm{i}$ »Gud Helligaand $\mathrm{i}$ Tro os lær«, og tager mange af mine Rettelser hos Kingo tilbage, da jeg seer, de let kan giøre Versene mindre levende for dem, de egenlig skal opbygge, medens det indskudte Lysglimt, om det end er ægte, dog ikke er for dem endnu.

Da det under disse Omstændigheder ikke kan være nødvendigt at tage noget overtvært, og jeg ventelig alt reiser Ugen efter Pindse, sees vi vel ikke, før jeg kommer igien, vil Gud, til Mikkelsdag, men, kiære Ven! 
tag Dem kun i Agt for Alt hvad der er Skin og Skygge, hvormed Fienden bestandig frister os baade indvortes og udvortes! Da vil Herren være med Dem og oplyse og styrke Dem, saa De kan voxe i Vorherres Jesu Naade og Kundskab, og da skal vi sees glade, fremfor Alt, naar Striden er stridt og Løbet fuldendt.

Denne Reise betragter jeg som min lille Deel i »Missjonen«, Gud lade den lykkes til Herrens Ære og Hans Menigheds Gavn, det veed jeg, De vil ønske med mig, og den Helligaand lære os at bede derom med vort Fadervor i Jesu Navn!

Kiærligst Hilsen fra os alle til begge Brødrene og deres Huse ved

Deres Ven

N. F. S. Grundtvig.

\title{
Breve fra og til Gunni Busck
}

\author{
Marts - Maj 1843
}

Fra Gunni Busck ${ }^{16}$

(Buscks salmeliste)

Kjære Ven!

Stiftsbjergbye 4de Marts 1843

Det var en Opskrivt paa de Psalmer til Tillæg, som jeg kunde synes om, jeg lovede Dig sidst, og den vil jeg her meddele, idet jeg deler dem efter den gamle Kirkes Viis med sine hellige Bøger i 1) dem, der ikke taale at modsiges og 2) dem, der kunne være Spørgsmaal om. Til de første regner jeg nu af Julepsalmer: 1) Et Barn er født i Bethlehem 2) Fra Himlen høit kom jeg nu her 3) I denne søde Juletid; af Paaskepsalmer: 1) Som den gyldne Sol frembryder 2) Op Sjel bryd Søvnen af 3) I Døden Jesus blunded i 5 Vers; af Pintsepsalmer: 1) Nu rinder op vor Pintsefest 2) Klar op mit Hjerte, Sjel og Sind 3) Gud Hellig Aand i Tro os lær 4) O Hellig Aand! som Pintse-Dag (: men i Kongens Navn maa 
forandres til i Jesu Navn om det ingen Misforstand skal give i vore aandløse Dage) - 5) Oprunden er vor Pintsefest $\div$ det sidste Vers. 6) O Hellig Aand, du Skat saa skjøn. - Psalmerne fra No. 25 til 32 i Hagens Psalmebog begge inclusive. Af Himmelfarts Psalmer: 1) Min Sjel og Aand opsving Du dig 2) Hos Gud, før Verdens Grund blev lagt 3) Saa knuste Christus Dødens Magt. Om Nadveren: 1) Fra Herrens egen Mund og Ord 2) O Jesu søde Jesu Dig 3) Enten »O Jesu din Hukommelse« eller din om det rette Livsens Brød, thi Menigheden maa dog nødvendigen udtrykke i sin Sang »at det er hans Kjød og Blod« hvilke Ord ei findes i den ny Psalmebog. Om Daaben: 1) Enhver som troer og bliver døbt 2) Mig lyster nu at træde 3) Jeg er frelst og dyrekjøbt. Desuden: 1) Frygt mit Barn den sande Gud 2) Af Høiheden oprunden er 3) O kjære Sjel! frygt aldrig meer 4) Jesu! din søde Forening at smage 5) Med Sorgen og Klagen hold Maade - i Mynsters Udkast. 6) Nu kom der Bud fra Englechor 7) Den Luft hvori vi gaae (: thi vi har nok om Skabelsen, men ikke Een, som fortæller at det var et Paradiis, som Gud havde gjort til Mennesket). 8) Naar jeg betænker den Tid og Stund 9) Fryd dig Du Christi Brud 10) Kom Hjerte! tag dit Regnebræt 11) Reis op dit Hoved, al Christenhed 12) Hvo veed hvor nær mig er min Ende. - See disse 40 vil jeg aldrig betænke mig paa at foreslaae istedetfor Udkastets de 40, og naar jeg nu opregner Nogle, som der kan være Spørgsmaal om, da er det ei fordi de jo nok vare værd at have med, men fordi det vist kun bør være et lille Tillæg og til en saa overordentlig ringe Priis, at den pecuniaire Betragtning aldrig kan holde nogen Menighed fra at anskaffe sig det. Snilde som Slanger og uden Falskhed, som Duer - siger Vor Herre og saaledes mener jeg, at vi med et godt, men lille Tillæg, skal underbyde det Andet, ikke for de gjerrige Sjeles Skyld, der maaler efter hvad der kan spares, men deels for de virkelig Fattiges Skyld og deels for de mange Børns Skyld, der langt snarere af Forældre faae Tillæget, naar det kun koster en 8 eller $12 B$ [Skilling]. De andre Psalmer, som jeg nu nævner, er det derfor egentlig ikke mit Ønske at see i Tillæget; thi det skulde være lille og kun indeholde det Nødvendigste; siden, naar den Frihed kommer, som Menigheden behøver paa sine gamle Dage, da driver en god Psalmebog fra Begyndelse til Ende vor nærværende usle aldeles bort! Amen!

Til Psalmer af anden Slags regner jeg da: 1) Saa skal dog Satans Rige 2) Er Gud for mig saa træde 3) Sørger Du endnu min Sjel 4) Nu har jeg fundet, det sig grunder 5) O Gud Fornuften fatter ei 6) Hvad kan os komme til for Nød 7) Gud Hellig Aand jeg flyer til Dig 8) O kjæreste 
Sjel op at vaage 9) Forsøm dog ei din Salighed 10) Bort Verden af mit Sind og Øie 11) Ind i det Allerhelligste 12) O Hellig Aand kom til os ned 13) O søde Gud din Kjærlighed 14) Den Idræt Gud er tækkelig 15) Hvor deilig skal Guds Kirke staae 16) Jeg gaaer i Fare hvor jeg gaaer og desuden af Sangværket mange, som jeg ei nu vil anføre; thi her er efter min Overbeviisning kun Talen om at faae igjen det Bedste af vor Kirkes gamle Psalmeriigdom, som er bortkastet i den ny, og ved denne Leilighed først bruge Dig, som den, der bedst har ændret hvad der var at ændre og dernæst lade et Par af dine Psalmer løbe med, fordi de staae de Gamle saa noer i Aand og Tone, at man mener de hører til, ja jeg nægter ikke, at saaledes som denne Sag staaer for mig, er det ikke af Grundsætninger, men af personlig Kjærlighed for Ingemann, at Een af hans er kommet med; thi den hører i Sandhed ikke til hvad den Deel af Folket, som savner sine gamle Psalmer, længes efter og i det jeg følger denne personlige Tilbøielighed, føler jeg meget godt, at andre har samme Ret til at begjære en af Bøie eller en anden nymodens Psalmedigter, som ikke modsiger vor christne apostoliske Tro.

Forresten kom nu snart kjære Ven med dette lille Tillæg og lad hende, som selv tilbød sin Bistand tage sig af det og Gud velsigne hende og os, at vi maae snart komme til at synge det - senest inden Pintsen, men helst til Paasken.

Om Kierkegaards Sag har jeg slet Intet hørt, men jeg haaber da, at naar der er noget Vigtigt paafærde, Du da lader mig det vide. For mine Øine er det i Sandhed klart, at Folk vaagne her i Menigheden, især i Mørke Sogn og det er mig derfor lidt underligt, at min Lyst til at komme $i$ et andet Kald tager snarere til, end af - Gud Fader bøie mit Hjerte efter sin gode Villie saa vil det jo nok som en levende Vandbæk risle til Velsignelse enten her eller andetsteds. Skuffende Forhaabninger veed Du er noget Helvedes Tøi og derfor ved Vor Herres Hjelp bort fra Hjertet med alle saadanne Snylteplanter. Saaledes gad jeg gjerne vide Sandheden i hvad den, jeg nævnte ovenfor, vilde tage sig af min Sag til at forfremmes i Nærheden af Kbh, hvis jeg skulde trænge til Bistand; thi Biskoppens Ord, hvor fine og venlige de end lød, sagde dog i Grunden, at derom kunde jeg intet Haab gjøre [mig]. At hun ved nogen Deeltagelse i Sagen mere vil skade end g[avne] mig, har jeg al Grund til at tro efter Stemanns Ord til Salig Bech, og om hun har Sind til ret for Alvor at tage sig deraf det kunde Vor Herre maaskee engang give Dig Leilighed til at erfare, helst naar Gladsaxe er givet bort; thi for at erholde det vilde jeg ikke gjøre et eneste Skridt meer end jeg har gjort. At jeg 
ikke ønsker det Mindste af hendes Bistand uden alene i Vor store Vens og Velgjørers velsignede Navn det kjender Han, som har givet mig Lyst til Brødet af sin Haand og Væmmelse til al Verdens Herlighed i en Andens Haand og det troer jo ogsaa dit Hjerte i Kjærlighed min Ven! saa Du vil ikke forplumre mig den Sag, som nu er reen og i hvilken jeg nu i Jesu Navn seer saa tillidsfuld op til Gud Faders Himmel, men kun klare i Sandhed hvad Vor Herre vil give Dig Naade til at kunne klare.Om Sorøe hører man ikke Noget og det er dog vist paa den høie Tid, hvis der skal vorde en dansk Dannelses Anstalt; men vil man end ikke nedsætte en Commission og give Dig en Plads deri hvad tør vi da vente? Og dog jo Gudskee Lov! vi tør vente alt Godt af Ham deroppe, naar vi kun ikke lade Ham have Ro og Fred for os, men gjøre med Ham, som Enken med den uretfærdige Dommer! Derfor - vi blive ved - det er ei forgjæves, det siger Amen.

Din Ven

G. Busck

\section{Til Gunni Busck ${ }^{17}$}

\section{Kiære Ven!}

Khvn. 7. Marts 1843.

Tak for din Liste, som jeg just idag havde tænkt paa at æske, hvis den ei var forekommet mig! Om de »Uimodsigelige« kan vi temmelig let blive enige, skiøndt der i Henseende til Passjons- Psalmerner dog er et "men" ved; men ved Indskrænkningen til de 40 , som er Bispens Gyldental, eller til de Gamle, er Du paa Vildspor, hvor jeg slet ikke kan følge Dig, thi baade lyder den Kongelige Opgave paa de »ældre og nyere « Psalmer, som mest savnes, og vor egen Konge siger at en Skriftklog, som er oplært til Guds Rige, fremtager af sit Forraad baade $N y t$ og Gammelt, og vi maae visselig ikke glemme, hvad vi mest savne, ikke som Personer af den lærde, dannede Verden, men som forholdsviis oplyste Medlemmer af Herrens Menighed og Hans Embedsmænd i den, men det glemde vi, naar vi intet Hensyn tog paa hvad Herren har lært os at savne ligesaavel i den Lutherske Psalmebog som i den Lutherske Lærebog, saa jeg kan slet ikke begribe, hvordan Du er kommet i Vilderede med det. - Et er nemlig, hvad vi kunde og skulde nøies med indtil videre og takke Gud til, naar Bispen bød os det, eller knappede af, men noget ganske Andet hvad vi, med Herrens Menighed og Dens Tarv 
for Øie skal foreslaae og bede om, thi det maa være det Bedste, vi for Øieblikket see Udvei til. Vor personlige Tilbøielighed baade til os selv og vore gode Venner skal vi vist nok alvorlig stræbe at holde udenfor Spillet, men naar vi giør det, ikke ængste os over det Uundgaaelige. I Henseende til Godtkiøb har Du vist nok Ret, men dertil see begge Fengerne med os en nem Udvei, og enten vi sælge 40 eller 100 Psalmer for 8-12 B bliver Sagen jo den samme, men for Kirken giør det en stor Forskiel, hvis vort Ønske opfyldes, og indføres virkelig vort Tillæg i endeel Menigheder, kan Prisen baade af sig selv blive lav, og en Forbindelse med de Præster, som hue det, giøre Anskaffelsen endnu lettere. - Paa Børnene skal vi her ikke tænke videre end at de i Kirken skal finde det Barnlige igien, thi deres lille Sangbog bør endnu være mere historisk end Hagens, og at skaffe dem ved Leilighed en saadan, der ogsaa er bedre Kiøb, bliver en egen Opgave.

Derfor, min Ven! lad mig smukt vide, hvilke af Ps. i Sangværket, Du veed Tone paa, og gierne saavel for Oplysningens som Opbyggelsens Skyld vilde høre i Kirken, thi jeg kan høit behøve Meddomsmænd i saa killen en Sag, som jeg dog ingenlunde maa afvise!

Hvad Tiden angaaer, da giælder det kun om at benytte den, thi jeg vilde ved denne Leilighed ligesaa nødig forhaste som forsinke mig, og skiøndt jeg naturligviiis med Dig ønsker bedre Kirkepsalmer heller idag end imorgen, vilde jeg dog være meget glad ved at faae dem til noeste $J u l, o g f ø r$ tør jeg neppe tænke det mueligt. - Det vil alt være store Ting, om den lille Psalmebog kan komme ud og lidt omkring til Pindse, thi skiøndt jeg sidder midt i det, kan jeg dog endnu ingenlunde see til Enden, og paa kiedelige Ophold hos Trykker og Binder maa man altid være belavet, men da vi i Kirken er blevet vant til at døie Ondt, giælder det heller ikke nær saameget om lidt snarere at faae det lidt bedre, som om med det Første ordenlig at faae det godt, og det haaber jeg til Gud, vi skal, naar vi bier lidt efter Ham.

Hvad Befordringen angaaer, har jeg intet at tilføie, uden hvad Du veed, at vi maae bede Gud give os i alle Maader sin Fred, saa vi ikke urolig hige efter Noget, thi kun da gives der hos Ham skuffende Forhaabninger. Begynder Marken omkring Dig virkelig at gulne til Høsten, da vil Du formodenlig ligesaa lidt for din egen som for Næstens Skyld nænne at skifte Plads, men om det virkelig er saa, veed igrunden kun Vorherre, og naar vi overlade Ham Afgiørelsen, kan vi være ganske rolige. - Din Lyst til at vide hvad Andre kunde have eller faae isinde at giøre dertil, finder jeg meget naturlig, thi det gaaer tit mig selv ligedan, 
men naar den Lyst bliver stærk hos os, er der intet andet godt Raad end at bede Vorherre dæmpe den, thi om Vedkommende var nok saa aabenhjertige og virksomme, er de dog aldrig paalidelige, og ved tvivlsomme Spørgsmaal maae vi desuden vogte os for at sætte alle Midler i Bevægelse til den ene Side, derom er eller blive vi sikkert enige.

Sorø hører jeg ikke det mindste til, men seer kun af Aviserne, at man dog trættes om det, og at Academiets Bestandighed paa Stedet til Folkegavn paastaaes, og det synes mig godt Tegn, og da jeg har naaet nogenlunde at lægge ogsaa den Sag i Guds Haand, finder jeg mig paa den ene Side rolig ved Udfaldet og paa den Anden bestemt til at giøre Alt hvad jeg kan faae Sind og Lykke til for at fremme hvad jeg veed er godt.

Kiærligst Hilsen fra os alle til Dig og Dine ved

\author{
Din Ven \\ N. F. S. Grundtvig
}

Fra Gunni Busck ${ }^{18}$

Kjære Ven!

Stiftsbjergbye paa de 40 Ridderes Dag [9/3] 1843

At Kongebudet lød paa de "ældre og nyere« Psalmer, vidste jeg ikke, men, at det var Savnet af de gamle Psalmer, der havde fremkaldt Begjæringen om Tillægget, det vidste jeg og maatte derfor med Grund antage det for rettest, at vi fik de uundværligste af de Mistede, skaansomt ændrede, igjen og ved samme gode Leilighed et Par af Dine indsmuglede, fordi de i Sandhed maae kaldes Hines aandelige Heelbrødre. Den Opgave, der efter hint Kongeord skal løses, er derfor langt vanskeligere og jeg vil rigtignok med Dig være glad, om den blot inden Juul kan være løst, naturligviis ei paa Papiret alene, men i vore Munde i Kirken. Altsaa til Sagen, som her er for mig at nævne efter din Begjæring dem i Sangværket, som ei allerede ere nævnte i min første Opskrivt og som jeg maa stemme paa, saavel for Oplysningens, som Opbyggelsens Skyld i Kirken. Jeg nævner dem da efter den Orden, de følge paa hinanden i Sangværket og begynder da med

1). No 6, dog med Forandring i sidste Vers: „Ved Luther vi faae dit Lys paa ny« istedetfor »tændte Lys« der kan misforstaaes, da Kirke-Lyset jo 
ei var slukket, men kun Øinene forkoglede af Pavedom. 2). No 14, 3). No 30, 4). No 46, men som den staaer i Hagens Psalmebog; thi saaledes lader den sig synge; det prøvede vi igaar ved Katechisationen i Kirken. Dog hellere Satan el. Djævlen end »Dragen« i første Vers. 5). No 67, 6). No 69, 7). No 73 med 9de og 10de Vers udeladte. Den gaaer deilig som: Gud Hellig Aand i Tro os lær', 8). Enten Luthers No 89 eller din No 90, hvis der er Psalmetone til dem. 9). Ogsaa No 101 under samme Betingelse. 10). No 108, som jeg har anført, maa med den søde Guds Hjelp paa ingen Maade savnes, som den staaer i Sangværket, 11). ligesaalidt som No 110, der er forbedret. Hos den tidligere foreslaaede No 116 staae 12). No 117, hvis den kan faae Plads; og ligeledes hos No 160 13). No 162, der begge gaae, som: O Jesu din Hukommelse. 14). No 200. 15). No 261. 16). No 270. I tredie Vers læs: "viiste« for »teede«. 17). No 275,18$)$. No 280 . Kunde vi nu med 19). No 301 ogsaa for det 20de). ॥Tage det sorte Kors fra Graven» (No 302) saa Jorden, hvergang den vaagner i den milde Vaar, maatte giennem alle vore Sandser for troende Hjerter prædike den store Opstandelse, ja da vare vi jo Gud være lovet! ret oven paa og maatte da ret med Glæde kunde synge 21). No 318, af hvilken vi dog give det sidste Vers til sin Eiermand No $289 \mathrm{og}$ synge det, som i forrige Dage: "Tak for Himlen, Du har inde (つ: er i Besiddelse af ) - Dér skal vi Dig see og finde». 22). No 345, 23). No 367, men »Herrens Segl« istedetfor »Kongens« og 24). No 370, som gaaer paa samme Melodie. 25). No 377, 26). No $378 \mathrm{og}$ den, der følger, har jeg bedet om. 27). No 382, hvis den har Tone, thi 28). No 383 har Tone og kan med Guds Hjelp lære dem, som synge den, at skjønne paa Daaben. 29). No 385 har Du rigtignok klaret kjære Ven! men Tonen: "O Jesu din Hukommelse" har den mistet; dog skjøndt jeg kun var $1 / 2$ Timestid ovre i Sommer med Ingemann paa Parnasset, kan jeg dog nok hjelpe denne Deilige til Tonen igjen, naar jeg maa, og det bliver da omtrent saaledes: $»$ Kom $D u$ Gud-Faders Aand fuldgod, Kom med dit Lys, med Kraft og Mod, Med himmelsk Smil og salig Graad! Stat $D u$ os bi med Raad og Daad! $O$ Talsmand, Trøster allerbedst! $D u$ til den store Bryllups-Fest Med Herrens (himmelsk) Viisdom os bereed, Fremvoxende i Kjerlighed. Byg Selv dit Tempel i vort Bryst! Gjør der med Flid det Mørke lyst, Vor Haardhed blød, vor Kulde varm, $O g$ Døden huusvild i vor Barm. Lad ret det kjendes hos os nu; $A t$ alle Tungemaal kan Du, $O g$ at, som Guldet regner ned, $S a a$ himmelsk er din Gavmildhed. $D u$ tæmme vore Fjender saa, At her vi Freden nyde maa, Vor Herres Fred, den store Skat, Guds Søn os Selv har efterladt, O gjør 
Gud-Faders Hjertelag, For os ret som den klare Dag, Og Sønnen paa sin Kongestol, Udstraalende, som Livets Soel. Ja giv os, med din Ydmyghed, Om Dig Guds Aand en god Beskeed, Saa ret det lever i vor (rinder os i) Hu: Gud! som Du vil, saa virker Du! 30). No 389. 31). No 390 med Udeladelse af det sidste Vers og Slutningen af det Næstsidste forandret til det Gamle: "Ja bind i Negen os med dem, Han gladelig skal føre frem.« 32). No 393, hvis den har Tone; den kunde [slutte] med: »Gjør selv Dødens Vandring let!« Tilsidst 33). No 397, 34). No 398 og 35). No 401, hvis de kan synges.

Dette kjære Ven! er hvad jeg formaaer at pege paa, og nu være Sagen Ham anbefalet, som vist vil tage sig af den. »Om Befordrings-Væsenet" ville vi helst tale mundtlig og det kan jo, vil Gud, skee i Mai Maaned. Kanskee jeg da ogsaa kunde være med at syne dit Udvalg, da Du jo Selv ønsker »Meddomsmænd«. Et Stykke af Carsten Hauch i Fædrelandet for at skille Sorøe latinsk Skole fra Academiet (imod Hjort) har jeg glædet mig over; ligesom jeg har ærgret mig over Flemmers Uforskammenhed i Fædrelandet med at foreslaae Skjærp[else] af Latinen i Skolerne for at lære vore Børn at skrive og tale godt Dansk; thi - siger han - det har Ingerslev bemærket i Preussen, hvor man lærer classisk Latin, dér skriver og taler man classisk Tysk; endskjønt han (Flemmer) selv tilligemed Mynster ved Roeskilde Skoles Indvielse maae bekjende, at det er daarligt bevendt med hvad man nu i Skolerne kan skrive og tale dansk. Dog Han, som er al sand Aandeligheds Fader, hjelpe os imod disse Uaander Dødbidere af alle Slags. Lad mig ved Leilighed vide hvorledes det gaaer Kierkegaard med Baptisterne og om han skulde behøve Vennehjelp i sin Knibe; thi gjør mod Andre hvad Du vil de skulle gjøre mod Dig - siger Vor Herre! Hils nu Dine og vær hilset!

Din Ven

G Busck

E.Sk. Jeg haaber, at her ingen Skrivefeil skal have indsneget sig med Nummerne; men da Posten bier, maa jeg sende det nu uden Gjennemsyn. 
Fra Gunni Busck ${ }^{19}$

Kjære Ven!

Stiftsbjergbye 23. Marts 1843

Hastværk er Lastværk, siger jo Ordsproget og jeg maa sande det, idet jeg her griber Pennen for at laste Noget ved den Opgivelse af Psalmer, jeg i Hast sendte Dig. »O Gud! Fornuften fatter ei«, som Du veed staaer i Mynsters Udkast, har jeg vist glemt at stemme paa, og jeg maa dog i 2 de Henseender give den min Stemme, baade objectivt og subjectivt; thi baade skildrer den herlig Sjelens Tilstand under Guds forunderlige Førelser og er gjennemaandet af en inderlig ydmyg og dyb Tillid til Guds Naade, og det var den sidste Psalme, jeg bad med min Salige Andrea, førend Gud gjemte hende.

Den Anden, jeg har glemt at spørge Dig, om Du ei nok varsomt kunde ændre lidt, er den deilige Nadver-Psalme: »O Jesu paa din Alter-Fod, Med Hjertens Tro, med Bøn og Bod « thi sandeligen den burde neppe heller savnes i dit Udkast. -

Hermed kunde jeg slutte; thi dette var hvad jeg maatte skrive; men nu vil jeg dog tilføie, at Satan har ladet høre fra sig i et Nabosogn i Skamstrup. Dér har nemlig en Ungersvend ved en Lystighed tilladt sig at forrette flere præstelige Handlinger og lyst Velsignelse og deelt $\varnothing 1$ af en Kande omkring med de Ord: "Det er Jesu sande Blod!« Sagen er vidnesfast og Bøgh har naturligviis betydet Karlen, som fremtraadte meget fripostig i den Sag, at han tog ham ikke til Alters, før han fortrød den Handlemaade og gjorde godt igjen, hvad han formaaede. Nu indberetter han den til Bispen, men efter sin egen Overbeviisning og alle Nabopræsters Raad med Begjoring at der ikke maa blive taget juridiskt fat paa den Sag, hvad kun kan give Forargelse, naar man kjender deres letsindige Fremgangsmaade ved Retten med Edens Aflæggelse og veed hvor liden Tro der findes hos Mange til at det er i Sandhed Herrens Legeme og Blod, som vi nyde i Nadveren. - Ja Gud see dog i Naade ned til os og skjænke os den Frihed i Kirken, som vi trænge til for, saa godt vi kan, at samle værdige Gjæster ved Herrens Bord; vi vide jo godt at de allerafskyeligste maae blive iblandt os til Herren selv bort[t]ager Hykler[iet,] men det er dog grueligt med denne Maade at betragte Nadveren og dens Nydelse paa, som en statsborgerlig Sag - det Maaltid, Vor Herre indstiftede, da han var huusvild i denne Verden og hans Egne snart skulde blive det! 
$\mathrm{Nu}$ - Guds Fred, og hører Du Intet fra mig før Metas konfirmation saa haaber jeg dog Gud hører mit: Vor Herre være med Eder!

\author{
Din Ven \\ G. Busck
}

Brev fra Grundtvig til Gunni Busck den 15. april, 1843 er trykt i Breve II, nr. 470 (og delvis i Busck p. 274 f). Brevet er skrevet påskelørdag og vidner om Grundtvigs arbejde med påskeprædikenerne og salmen: At sige Verden ret farvel, der kom med $i$ Psalme-Blade til Kirke-Bod i en første version. (Jfr. min artikel i Grundtvig Studier 1997 p. 148 ff.). Da brevet ikke rummer noget direkte om salmebogen, udelades det her.

\title{
Til Gunni Busck ${ }^{20}$
}

\section{Kiære Ven!}

Khvn. 6te Mai 1843

Vi spøgede sidst med Reisen til Oxford, men hvor let Spøg kan blive til Alvor, saae jeg igaar, da jeg aldeles uventet fik et Brev fra Dronningen, hvori Hun meldte mig, at Hun længe havde ønsket mig en Engelands-Reise, og var nu endelig istand til at give mig den. Du kiender min Tankegang derom, saa det modtog jeg naturligviis som vor Herres Tilbud, Han nok Selv vil give Kraft og Held til baade at følge og benytte, saa, vil Gud, reiser jeg Ugen efter Pindse og tager Svenn med, hvis boglige Retning jeg nu ogsaa seer, Vorherre bifalder og giver ham en ganske overordenlig Leilighed til frugtbar at følge, Gud give ham ogsaa Alvor og Sind dertil!

Saa skal jeg da, rimeligviis, for Alvor støde sammen med de halve og hele Papister i Oxford, og det nytter ikke at dølge for sig selv, der vil findes haarde Halse og uomskaarne Hjerter, saa Møien er vis og Virkningen meget tvivlsom, Gud give i Jesu Navn baade Viisdom og Taalmodighed!

Imidlertid staaer denne Reise ingenlunde sørgelig for mig, og naar jeg kun kan bevare den Sagtmodighed, der bør findes, hvor jeg ikke optræder som Missionær, men som Forsvarer af Mortens og vor Deel baade i den Catholske Kirke og Vorherre Jesus, da tør jeg nok haabe at 
meddele de Godtfolk i det mindste lidt bedre Forstand paa Kirkehistorien og deres eget Løsen "qvod ubique, semper et ab omnibus, " maaskee ogsaa at give den indbrydende Tydskhed en Rap, og den folkelige Retning et Skub, thi hvor der ikke er noget i Veien, vil Puseyiterne ganske anderledes forstaae mig end Folk heromkring.

Du kan nok tænke, at der gaaer meget rundt i Hovedet i disse Dage, saa det er alt Det, jeg kan overkomme med et Par Linier at melde Dig denne engelske Revolution i alle mine Sysler og Anstalter. -

Den lille Psalmebog maa nu ligge til Mikkelsdag, da jeg, om Gud vil, kommer hjem, men jeg haaber dog at faae den færdig, og nedlægger den da hos Theodor Fenger, hvor Vennerne, naar de komme herind, kan see den, og, hvis det skulde giøres behov, i sin Tid, tage sig af den. Birchedal har skrevet en deilig lille Bog om Kirkeaarets Evangelier, som Du endelig maa læse, thi den har ikke blot glædet men virkelig oplyst mig, saa uden den kunde jeg ikke sluttet min Psalmebog, som jeg dog følde, det maatte være, med et ordenligt Hensyn paa vore Evangelier.

Kiærligst Hilsen fra os alle ved

Din Ven

N. F. S. Grundtvig

Resten af maj måned er der en livlig brevveksling mellem Grundtvig og Gunni Busck, inden afrejsen til England onsdag efter pinse d. 7. juni. Brevene er trykt i Busck. Da de ikke omhandler salmebogen, gengives de ikke her. Grundtvig skriver den 19. maj bl.a.:

Kan Du komme herind før jeg reiser, saa giør det, for jeg længes efter den Hellige Nadver og synes dog ikke, jeg har Glæde af at nyde den hos dem, der forrette den ligesom Jordspaakastelse. Til Nød kunde det skee efter Pindse, den samme Onsdag, jeg formodenlig reiser, men heller vilde jeg det Onsdagen før Pindse, og jeg veed, din Kiærlighed vil giøre langt mere for mig end det, naar det kan føie sig! Nu Gud i Vold! $---{ }^{21}$ 
Svaret fra Busck af 21. maj 1843 er utrykt ${ }^{22}$ og lyder:

Fra Gunni Busck

Kiære Ven!

Stiftsbjergbye 21. Mai 1843.

Tak for Dagens Epistel. Vil Gud, kommer jeg til Kbh. d. 29. Mai for at prædike i Vartou Kirke Onsdagen d. 31. Mai og tage dem af Vor Herres Venner, som dér forefindes og ønske det, til Hans Bord.

At jeg saaledes idag Intet mere har at tale med Dig med Pen og Blæk undrer Dig vel neppe.

Din Ven
G. Busck

\section{Breve fra og til Peter Rørdam}

Marts - April 1843

Brevvekslingen i foråret 1843 mellem Grundtvig og Peter Rørdam findes i: Peter Rørdam. Blade af hans Levnedsbog og Brevvexling fra 1806 til 1844. Udg. H. F. Rørdam. Kbh. 1891. (Rørdam).

Undtaget er dog netop Peter Rørdams brev af 10. marts 1843 med Rørdams salmeliste. Dette brev anføres derfor nedenfor. For sammenhængens skyld bringes også den efterfølgende diskussion om salmerne mellem Grundtvig og Peter Rørdam (i uddrag fra de trykte breve).

I brev fra Peter Rørdam til Grundtvig d. 21. Febr. 1843 skriver Rørdam bl.a: »Naar De seer Boisen - vil De saa minde ham om Deres Tale og Bispens Psalmebog«. (Rørdam. p. 283).

Grundtvig svarer Rørdam i brev af 28. februar bl. a.: ${ }^{23}$ 
Kjære Ven!

Kbhvn. 28. Febr. 1843.

Jeg har sagt det til Boisen baade om Nyaars-Ønsket og Psalmeheftet, saa nu faar De vel begge Dele og kan see, hvad De synes baade om Hr. Peders Vise og om Bispens Psalmesmag og Takt. - Hvad mig angaaer, da synes jeg kun temmelig godt om den Første og slet ikke om den Sidste. Derfor vil jeg prøve at giøre en lille Samling, der i det mindste tigange bedre løser Opgaven med »de ældre og nyere Psalmer, som meest savnes « i den forlorne Psalmebog, og jeg har i den Anledning bedt Fengerne nævne mig de Psalmer og Melodier, som de og deres Kirkegængere meest savnede, men vil nu bede Dem om det Samme, for, saavidt mueligt, at vælge det folkeligste i alle Maader! Om det da vil blive os tilladt at bruge et saadant Tillægshefte i Kirken, er vist nok i Mynsters Dage meget tvivlsomt, men dels er det dog immer af de mulige Ting, dels vil det dog da holde haardere at paanøde os noget aabenbar langt fattigere, og endelig lever M. ikke evindelig. - Husk Dem nu derfor rigtig om og lad mig saa faae Deres Liste, da Sagen ei taaler Opsættelse.

Deres

Grundtvig

Fra Peter Rørdam ${ }^{24}$

(Rordams Salmeliste)

Kjære Pastor Grundtvig!

[10. marts 1843]

Her har De nu min Psalmebog:

1. Der sad en Jomfru i Nazareth.

2. Et Barn er født i Bethlehem.

3. Guds Engle sang i Stjernetal.

4. Velkommen igjen Guds Engle smaa.

5. Marie Hun sad paa Hø og Straa!

6. I denne søde Juletid.

7. Vor Herre Han var en lille Dreng.

8. Deilig er den Himmel blaa.

9. I Nazareth der var saa smukt! Mel. Svend Vonved sidder i Bure. 
10. Herrens Røst var over Vandet.

11. Mig lyster nu at træde.

12. Alt paa den vilde Hede.

13. Der sad en Fisker saa tankefuld.

14. Hvad er det for en Snekke! Mel. Hr. Esben tjener i Kongens Gaard.

15. Blomst kan visne før Soel gaaer ned.

16. Om en Hedning vil jeg sjunge.

17. Kistelagt var Enkesønnen.

18. Moder-Hjerte hvor du findes.

19. Brudgom taler til Bruden sin. /: Berner Rises Tone - liflig./

20. Hører til I høie Himle.

21. Over Kedron Jesus træder.

22. Længe havde Satan spundet.

23. Ingen Høihed ingen Ære.

24. Jesus, som skal Verden dømme.

25. Gak under Jesu Kors at staae.

26. I Qveld blev der banket paa Helvedes Port.

27. I Graven laae den Herre Xst.

28. I Døden Jesus blunded.

29. Som den gyldne Soel frembryder.

30. Op Sjæl bryd Søvnen af.

31. Tag det sorte Kors fra Graven.

32. Hvor lifligt er det dog at gaae.

33. Jesus lever - Graven brast.

34. Lov og Tak og evig Ære.

35. Vai nu Dannebrog paa Voven.

36. Til Himmels foer den Ærens Drot.

37. Nu rinder op vor Pindsefest.

38. Fra Himlen kom den Hlaand.

39. Oprunden er vor Pindsefest.

40. Den signede Dag med Fryd vi see.

41. Klar op Du Sky paa Øienbryn.

42. Klar op mit Hjerte, Sjel og Sind.

43. Gud Hl.aand i Tro os lær.

44. Vi troe som vi ved Daaben svoer.

45. Frygt mit Barn den sande Gud.

46. Jeg er saa underfuld en Magt.

47. Søde Jesus Julens Fyrste. 
48. Natten skrider, Dagen gryer.

48.(!) Glæd Dig Zion, glæd Dig Jord. Ingemann.

49. I Wittenberg.

50. Som den gyldne Soel udbryder. - N. 59 hos Hagen.

51. O havde jeg Vinger.

52. Stille Zions Døttre smaa.

53. Guds Kirke er saa fast en Borg.

54. Nu ringer alle Klokker mod Sky. No. 63 hos Hagen, - men 3. Vers - saaledes: For os Han foer til Helvede ned. -

55. Nu titte til hinanden de fagre Blomster smaa. Ingem.'s Morgensang.

56. Hvor salig er den lille Flok.

57. Nu rinder Solen op.

58. Hvad est Du dog skjøn. No. 31 i Brorsons Svanesang. Tonen yndelig.

59. Den store hvide Flok. No. 69 Brorsons Svanesang. Tonen glimrende og let.

60. Op al den Ting, som Gud har gjort.

61. Befal Du Dine Veie. - Tonen skjøn.

62. Naar jeg betænker den Tid og Stund.

63. Som Markens Blomst henvisner fage.

64. Skjøn Anna.

65. Med Sorgen og Klagen hold Maade.

66. I Verden er ei Nød saa stor. No. 593 hos Bispen.

67. Udrundne er de gamle Dage.

68. Lover Herren Han er nær. No. 4 hos Hiort.

69. Sorrig og Glæde vandre tilhobe.

70. Hvor deilig er den unge Vaar. XI hos Boie.

71. Hvad vil Du med den Ønskeflok. Boie, XII.

72. Farlige Veie. Boie, III.

73. Lidt kun det baader, at Mesteren Huset bygger. -219 hos Hiort. - Tonen er stolt, seirig.

74. Tusind Aar stod Xsti Kirke.

75. For al den Deel, som Gud har gjort.

76. Kirken er et gammelt Huus.

77. Hos Herren paa det Høie.

78. Nu bede vi den Hlaand.

79. Herren han sagde til Herren min.

80. Steen for mig skal raabe. 
81. Xstus er vores.

82. Verden er som man den tager.

83. Ordet var fra Arilds-Tid.

84. Som Hønen klukker mindelig.

85. Som Hjertet slaaer i Glædens Stund.

86. I Jesu Navn bør al vor Gjerning skee.

87. Kommer hid kun med de Smaa.

88. Fader vor i Himmerig.

89. Dækker Gud nu Bord i Ørken.

90. Smuler under Herrens Bord.

91. Herre! hvor skal vi gaae hen.

92. Jeg veed et Himmerige.

93. Kan gamle Folk gjenfødes.

94. Vor Alderdoms Trøst og Støtte.

95. Som Høielofts-Sale.

96. Af Høiheden oprundet er.

97. Søde Jesus vi er her.

98. Det lakker nu mod Aftenstund.

99. Vi samles for Dit Aasyn her.

100. Søndag Morgen fra de Døde.

101. En Sædemand gik ud at saae.

102. Held den Mand som frygter Gud.

103. Fra Solens Vugge til Solens Grav.

104. Stjernernes Skaber.

105. Fra Himlen høit.

106. Min Sol, min Lyst og Glæde.

107. Jesus Dine dybe Vunder.

108. Naglet til et Kors paa Jorden.

109. Jesus i Din Død er Livet.

110. I Verden mon være de Sygdomme to.

111. Har Sorg og Frygt mit Lys udslukt.

112. Dødning Gud er ei vor Drot.

113. Vuggens Engel.

114. Min Harpe jeg til Sang om Bjerget stemmer.

115. Kom o $\mathrm{H}[1]$ aand kom brat!

116. Du som udgaaer fra den levende Gud.

117. Mindes vi en fuldtro Ven.

118. Kom Gud Faders Aand fuldgod.

119. Syndernes Forladelse. 
120. Reis op Dit Hoved!

121. Sørger ei for dem, der sove.

Saa mangler jeg:

1. Psalme til en Vaarpræken - om Fuglene og Lilierne. - Mel. Jeg gik mig ud en Sommerdag - el. Den Sommer og den Eng.

2. Høstpsalme - om hele Bondens Liv - Sommeren igjennem - Mel. Kongen raader for Borgen.

3. Forsag Diævelen - efter Niels Ebbesens Tone - Ml. Kongen raader for Borgen.

Saa - nu kommer her Fremmede - Resten paa Søndag - Gud give os Lykke - saa skal det gaae muntert -

Hilsen kjærligst fra os alle.

Deres inderligt hengivne

Rørdam

Mehrn 10. Marts 43.

En Vaarsang - efter Agnete og Havmanden.

Fra Peter Rørdam ${ }^{25}$

Kjære Pastor Grundtvig!

[14. marts 1843]

Det var i saadan Fart, jeg sluttede i Fredags, da Fabritius kom, saa jeg maa sige endnu et Par Ord, om den nye Psalmebog, som ret vilde fryde os - blot jeg fik nogle af de Psalmer, jeg havde opskrevet - nemlig - at skal Sangen komme i Gang, maa Tonerne ogsaa være lette, helst have Lighed med Kæmpeviserne, og Versene være paa 4 Linier. Alle de Psalmer af den Verseart strømmer ind som sød Mælk, f. Ex: i Onsdags lærte Ungdommen hele den »Brudgom taler til Bruden sin«, og det gik med en Kraft, som var lystelig. - »Jeg er saa underfuld en Magt«, synger vi nu paa »Der stander et Slot i Østerrig«, men lettere gaaer den endnu efter »Kongen raader for Borgen « kun mangler der saa Omqvæden, som De vil meget fornøie mig ved at sende mig.

Derfor ønskede jeg saa gjerne en ny og let Psalme, istedetfor No 3, som vi synge hver Søndag, og endnu synge meget slet. Den gaaer saa trøvt og søvnigt, at jeg ærgrer mig hver Søndag. - 
Nu er det ogsaa en Uskik - ved Daaben - at synge 3 Psalmer (392 $247-556-$ ), det forstyrrer - bedre een god - og saa blive ved. -

De 2 af Brorson gaaer efter ganske yndige Melodier. -

I Søndags prækede jeg i Ørslev. Lund var reist til Falster, Hans Fader er syg. Det er kun en lille Kirke, og de store Piller tager Lyden bort, saa Menigheden synger $i$ et Hjørne, naar Degnen er $i$ et andet. Der var kjønne Mænd. -

Sorøe! Da jeg fik fat paa Avisen, blev jeg ganske fornøiet - men - da jeg saae, hvad det blev, maatte jeg ryste paa Hovedet af den høivise Direction - een Rector meer -

Forsamlingerne har jeg ikke mærket til - senere - derimod udbreder de sig i Egitsborg -

Sogneforstanderne og Bondestanden fra de 7 sydlige Sogne holdt igaar et stort Møde i Lundby. - Her er en Bonde, som har svoret Herremændene Død og Undergang - og han er smuk - veltalende - og meget oplyst - Peder Hansen af Lundby - han førte Ordet. - Jeg skal senere, naar jeg faaer ret Underretning, fortælle Dem det. -

Deres hengivne

Rørdam

Mehrn 14. Marts 43.

Nei bange blev min Kjæreste ei - men hun kunde ei strax blive fortrolig med Deres Personlighed - Hun og Bolette hilser kjærligst.

\section{Til Peter Rørdam ${ }^{26}$}

Kiære Ven!

Khbvn 24. Marts 1843

Den Prosit, som kom seent, er bedre end aldeles ingen, men lidt Hastværk har De havt med alt det, og det ved De nok, duer ikke. De har saaledes nævnet mange flere end „Jeg er saa underfuld en Magt« uden enten først eller sidst at sige mig, paa hvad Tone de kan gaae; saasom: »O havde jeg Vinger«, og »Stille, stille, Zions Døttre«, »Hos Herren paa det Høie«, »Herren han sagde til Herre min«, »Stene for mig skal raabe «, »Smuler under Herrens Bord", »Herre, hvor skal vi gaae hen«, »Vuggens Engel« o.s.v., hvoriblandt en Deel dog ogsaa har min Stemme. - Mindre er det, at jeg ei kan giætte, hvad Stregen betyder, som endeel har faaet, da den, anvendt paa dem alle, hverken kan sige, at de fattes Tone eller noget andet, jeg har giættet paa. - For Resten maa jeg 
nødvendig temmelig skarpt skielne imellem Kirke og Skole, da det ikke giælder om en heel Psalmebog, hvor det ikke skadede, der var nok til begge, men om en Nødhjoelp for Kirken, hvor man umulig kan optage alt hvad Folk kan ønske at synge, men skal kun see til at give det nødvendigste paa en Maade, saa Folk kan have Lyst til at synge det med hinanden. Kirken selv og hvad der enten er væsenlig for den, som Daab og Confirmation, Altergang og Præstevielse, eller hører dog til vor Kirketjeneste, fra Brudevielse til Liigbegiængelse, maa tilligemed Høitiderne og Søndags-Evangelierne være hvad jeg tager først, og Resten maa da med faa Undtagelser overlades til Skolen og Huset, som, naar de føle deres Trang, let vil finde den tilfredsstillet.

De egenlig historiske Sange vil da her ligesaalidt finde Plads som de blot efter Smagen opbyggelige, og Kæmpevisetoner, som slet ikke kan angives i et Udtog, vi tør vente Lov til at bruge i Kirken, er heller ikke der paa deres rette Sted; de høre til Skolen, og saavidt det kan skee, uden at bryde overtvært, skal vi ligesaavel stræbe at løse Folkebaandet i Kirken, som Kirkebaandet i Skolen; thi ligesaalidt som Christendom er Danskhed, ligesaalidt er Danskhed Christendom, og dog er det Christendom og slet intet andet, vi i Kirken skal vente, søge og finde. Lod vi derfor Folkeligheden oversvømme Kirken, da skabde vi kun et nyt Kaos istedenfor det gamle, hvori Christendom oversvømmede Skolen; men Sandhed siger: hver sit!

Til at klare dette og alt Andet skulde Sorø være Brændpunktet, og med Guds Hjælp bliver det vel ogsaa Enden, skiøndt det endnu seer broget ud. - - -

Det er mig kiært, at Forsamlingerne ikke har hjemsøgt Dem, men hvor Kirken har Christendom, og det Folkelige lever op i Skolen, har det mellem Sællandsfarer ei synderlig Fare.

De, deres Syster og Kiærest hilses venligst fra os alle ved

\section{Deres}

Grundtvig.

Efterskr. Jeg har omtrent faaet det i Orden med Kirke, Daab, Altergang, Præstevielse, Kirkevielse (hvortil jeg har gjort en Sang paa den yndige Melodi til Brorsons: »Her vil ties, her vil bies«), Søndagen, Jul, Fasten og Paaske, samt med Brudevielse, (hvortil en ny Sang er gjort, vel efter et tydsk Mønster, men dog i saa dansk Smag, at Melodien vist finder sig). 
Fra Peter Rørdam ${ }^{27}$

Kjære Pastor Grundtvig!

[7. april 1843]

Af Psalmerne, De nævner kjender jeg kun Tone til: Jeg er saa underfuld en Magt, der synges som: Kongen raader for Borgen! men mangler da et Omkvæd, som jeg gjerne ønskede De sendte mig - eller ogsaa som: Der stander et Slot i Nordsjælland. At jeg til mange af Psalmerne ingen Tone har anført, kommer deraf, at jeg endnu venter paa den, men har ingen kunnet finde - men - vilde derfor just have dem i Samlingen, at man des snarere kunde faae dem sat i Gang.

Min Streg har samme Betydning, som ellers, naar man understreger Noget, den er sat under de Psalmer, jeg særdeles ynder. -

Hvad De siger om Forskjellen mel. Skole og Kirke, synes mig dog ikke kunde hindre Kæmpevisetonerne fra at blive anvendte i Kirken, ligesom det er jo dog »i det danske Tungemaal « at Christendommen bliver udtalt, og vi ingen Melodier har fra Apostlernes Dage. -

Om de almindelige Kirkemelodier maae man sige: 1. de er ikke udrundne i vort Folk, men hos et fremmed, 2. opstaaede hos et Folk, der dyrkede Musiken som Kunst, og kan derfor vanskelig tiltale Mennesker, der ei er ret musikalske - derfor ogsaa Vers paa 8-10 Linier - som er jo et heelt musikalsk Værk. Derfor har jeg tænkt, at naar Guds Ord i gudelige Sange kunde blive lempede efter Toner, vi kjendte og elskede, var det det Samme som, at vi sang Dansk, ligesom vi nu præker Dansk. Jeg mener, Kæmpevisetonen er vor Musiknatur, derimod i Italien eller Tyskland, der passer vist vore Psalmemelodier meget godt. Og det har jeg erfaret, at f. E.: »Hvo ikkun lader Herren raade«, den er vi slet ikke sikkre i endnu, ei engang i »Alene Gud i Himmerig«! skjøndt vi synge den hver Søndag - men derimod »Et Barn er født i Bethlehem « »Nu titte til hinanden « og »Op al den Ting «! vi havde ikke sunget dem 2 Gange, før de slog igjennem saa det var en Lyst.

Det beviser altsaa, at vil man have Sangen til at gaae, maa man ogsaa have andre Toner; thi de gamle falde ikke ret i Øret - idetmindste ikke i mit - de er for tykke. Naar Verset er paa 4 Linier, saa bliver Tonen let og flydende. -

2. April havde jeg en stor Forsamling, og den var levende. - Folk kom til at tale med hinanden. - Vi sang: "I hundrede Aar satte Fienden ei Fod« og vil Gud, komme vi ogsaa med 28. Mai - og haaber, det vil blive smukt. 
Kanskee gjør jeg - efter Confirmationen en lille Tour ind til Dem, saa kan jeg mulig faae Psalmebogen hjem med. -

Hos Aagaard var jeg igaar. - Jeg har fornøiet mig over, at Mr. Svenn har bragt det saavidt, at han kan sige mine opera. Johan - nu skal han vel op. - Hils Meta - Deres Kone - og Svigerinde og Glahns!

Mehrn 7. April 1843.

Deres hengivne

Rørdam.

\section{Noter}

1. Enten i: Breve fra og til N. F. S. Grundtvig, udg. af Georg Christensen og Stener Grundtvig, Kbh. 1926 (Breve II), eller i: Gunni Busck, et Levnedsløb i en Proestegaard. Udg. af Henr. Bech, Kbh.1878 (Busck), eller i: Peter Andreas Fenger, en levnedstegning ved Frederik Barfod. Kbh. 1878, eller i: Peter Rørdam. Blade af hans Levnedsbog og Brevvexling fra 1806 til 1844 udg. af H. F. Rørdam, Kbh. 1891, (Rørdam 1).

2. Breve II, nr. 461. (Grundtvig-Arkivet, Fasc. 462).

3. Fasc. 412. (Brevet fra Grundtvig til Ferdinand Fenger mangler).

4. Fasc. 462.

5. Fasc. 385,4 .

6. Breve II, nr. 463. (Fasc. 462).

7. Fasc. 462.

8. Breve II, nr. 465. (Fasc. 462).

9. Breve II, nr. 466 og Fasc. 462.

10. Breve II, nr. 467. (Fasc. 462).

11. Fasc. 412.

12. Fasc. 462.

13. Breve II, nr. 469. (Fasc. 462).

14. Fasc. 462.

15. Breve II, nr. 473. (Fasc. 462).

16. Fasc. 460.

17. Busck p. 272 ff., Breve II, nr. 464 og Fasc. 460.

18. Fasc. 460.

19. Breve II, nr. 468. (Fasc. 460).

20. Busck p. 275 f. (Fasc. 460 ).

21. Busck p. 290

22. Fasc. 460. 
23. Rørdam, 1, p. 283. (Fasc. 463. Afskrift! - Desværre findes Grundtvigs egne manuskripter til brevene til Peter Rørdam ikke i Grundtvig-Arkivet - kun en afskrift.)

24. Fasc. 464 .

25. Rørdam 1, p. 285 og Fasc. 464.

26. Rørdam 1, p. $286 \mathrm{ff}$ (og Fasc. 463 Afskrift).

27. Rørdam 1, p. 289 ff. (Fasc. 464). 